\title{
Early Carboniferous ammonoid faunas and stratigraphy of the Montagne Noire (France)
}

\author{
Dieter Korn ${ }^{*}, 1$ and Raimund Feist ${ }^{* *, 2}$ \\ ${ }^{1}$ Museum für Naturkunde der Humboldt-Universität zu Berlin, Invalidenstraße 43, D-10115 Berlin, Germany \\ 2 Institut des Sciences de l'Evolution, Université Montpellier II, F-34095 Montpellier, France
}

Received 20 November 2006, accepted 5 February 2007

Published 1 August 2007

With 20 figures

Key words: Ammonoidea, Carboniferous, Montagne Noire, biostratigraphy, lithostratigraphy.

\begin{abstract}
The early Carboniferous (Mississippian) sedimentary succession of the Montagne Noire is subdivided into three major lithostratigraphic units, in ascending order the Montagne Noire Griotte Group (Devonian to Early Tournaisian), the Tournaisian to Viséan Saint-Nazaire Group (with the Lydiennes, Faugères, Colonnes, and Puech Capel Formations, the latter new), and the Laurens Flysch Group (late Viséan). The ammonoid assemblages in these rock units are reviewed. A total of 29 Early Carboniferous ammonoid taxa at species level are determined. The new genus Nigrocyclus n. gen., and the new species Gattendorfia nazairensis n. sp., Globimitoceras albaillei n. sp., and Neogoniatites canovasi n. sp. are described.
\end{abstract}

Schlüsselwörter: Ammonoidea, Karbon, Montagne Noire, Biostratigraphie, Lithostratigraphie.

\section{Zusammenfassung}

Die unterkarbonische Abfolge von Sedimentgesteinen in der Montagne Noire wird in drei lithostratigraphische Einheiten untergliedert, von unten nach oben die Montagne Noire Griotte Gruppe (Oberdevon bis Untertournai), die Saint-Nazaire Gruppe des Tournaisium und Viséum (mit den Lydiennes Faugères, Colonnes und Puech Capel Formationen, von denen die letzte neu ist), und der Laurens Flysch Gruppe (Oberviséum). Die Ammonoideen-Vergesellschaftungen in diesen Gesteinen werden revidiert. Insgesamt werden 29 unterkarbonische Ammonoideen-Taxa auf Artebene aufgeführt; neu beschrieben werden die Gattung Nigrocyclus n. gen. sowie die Arten Gattendorfia nazairensis n. sp., Globimitoceras albaillei n. sp. und Neogoniatites canovasi $\mathrm{n}$. sp.

\section{Introduction}

The Montagne Noire shows a Carboniferous rock succession, which constitutes a sedimentary sequence that developed from a pelagic platform into a synorogenic flysch basin (Engel et al. 1978, 1982). Biostratigraphic alignments of some of the lithological units and exact timing of the change in sedimentation, however, remain unclear because of the paucity of discrete index fossils. The age of the black cherts ('lydiennes') and the onset of the flysch have remained misinterpreted for a long time.
In the following account, the Carboniferous ammonoid faunas of the Montagne Noire are revised. This is possible because the majority of the specimens collected by Böhm (1935a) and his contemporaries are available in the collection of the Institut des Sciences de l'Evolution, Université Montpellier II (ISEM). Additional collections were assembled during the last 30 years by several researchers, and form a solid basis for such a revision.

With the advances in ammonoid stratigraphy in other regions such as the South Urals (e.g. Ruzhencev \& Bogoslovskaya 1971), the Northern Urals

\footnotetext{
* Corresponding author: e-mail: dieter.korn@museum.hu-berlin.de

** E-mail: rfeist@isem.univ-montp2.fr
} 


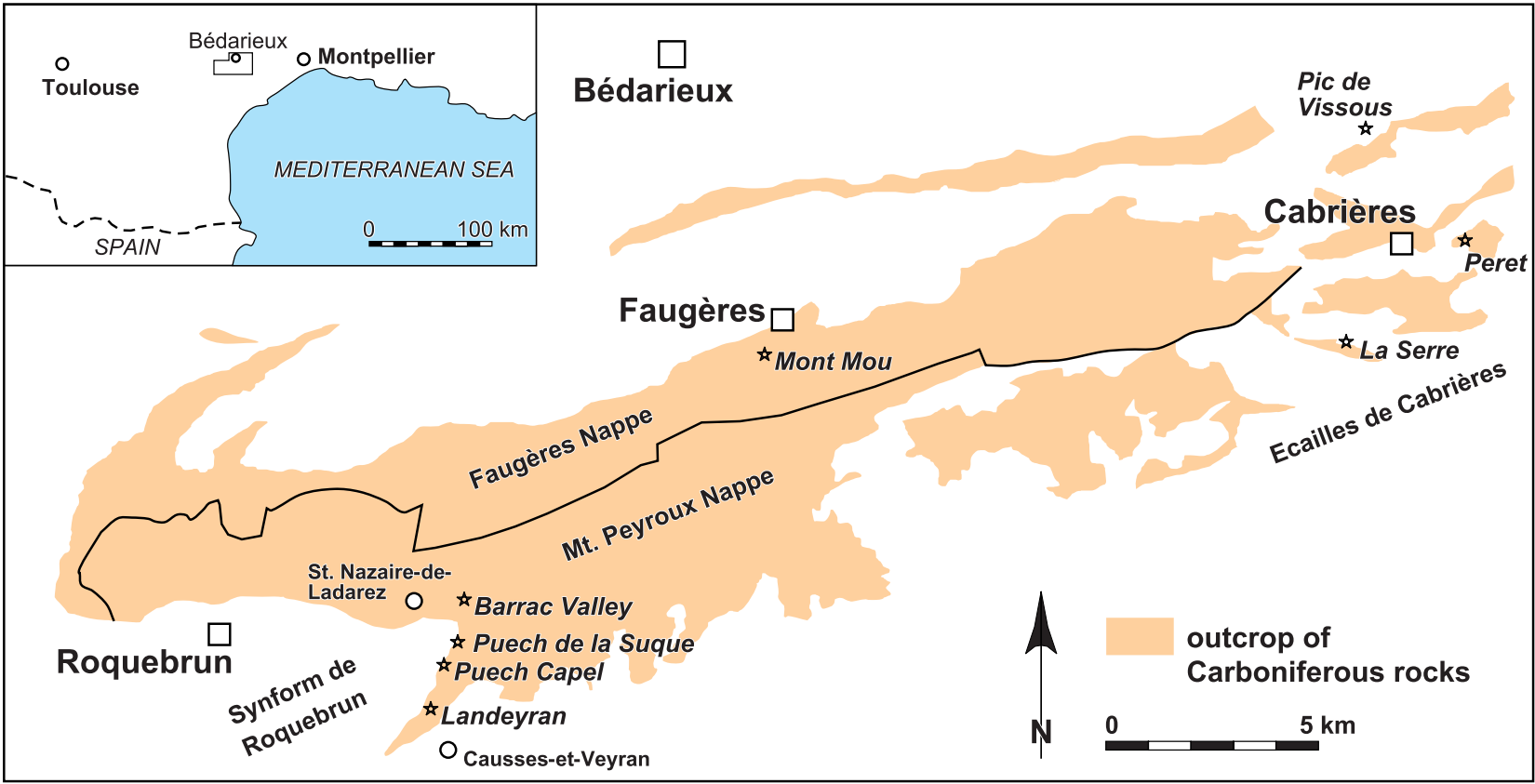

Fig. 1. The outcrop of Carboniferous rocks in the Montagne Noire and the geographic position of the ammonoid localities.

(e.g. Kusina 1980), and North Africa (Korn et al. 2007), the assemblages of the Montagne Noire can be interpreted more precisely. Correlation of the ammonoid-bearing horizons with the standard stratigraphic schemes is now possible.

Carboniferous ammonoid-bearing rocks are long known from the Montagne Noire (von Koenen 1883; Bergeron 1899a, 1899b; Theron 1899), thereafter it was not until the midthirties that two articles, which figured ammonoid specimens were published. The first one was provided by Gaston
Delépine (1935), who in a brief note described "Aganides sp." and "Pericyclus niger sp. nov." from phosphoritic nodules within the lydite horizon that is exposed at numerous places in the vicinity of Cabrières (Fig. 1).

The monograph by Rodolphe Böhm (1935a) was released in the same year; it is the most extensive description of the Carboniferous ammonoid faunas of the Montagne Noire. Böhm listed and figured ammonoid specimens from four different Carboniferous rock complexes (see Fig. 2):

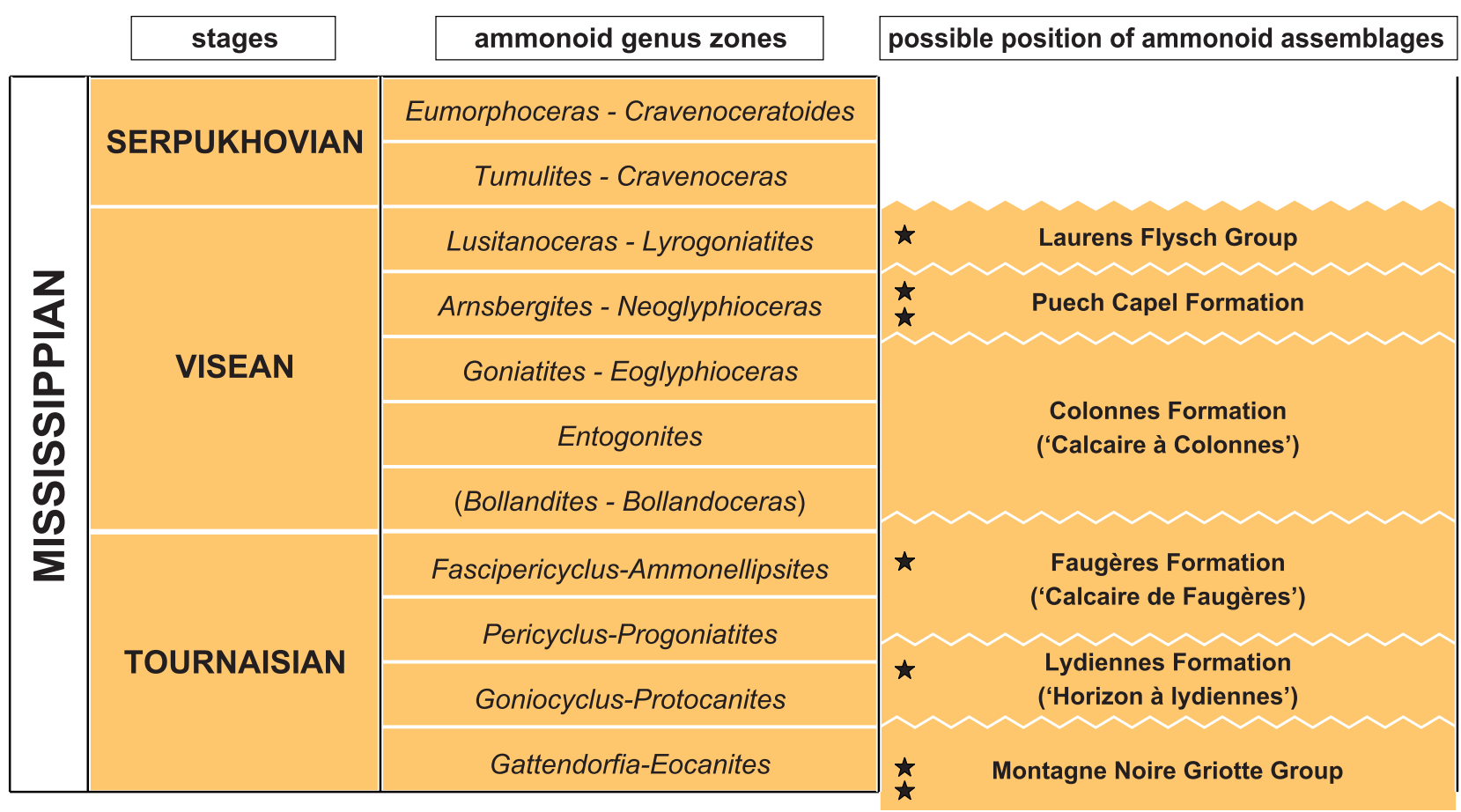

Fig. 2. Stratigraphic scheme, genus zones, and Tournaisian and Viséan rock formations with ammonoid assemblages (indicated by an asterisk) in the Montagne Noire. 
'Horizon à lydiennes' (= Lydiennes Formation); horizon of black cherts with phosphoritic nodules:

"Aganides ornatissimus de Koninck" = Globimitoceras albaillei n. sp.

"Pericyclus Kochi Holzapfel" = Gattendorfia nazairensis n. sp.

"Pericyclus Hauchecornei Holzapfel" = Gattendorfia nazairensis $\mathrm{n}$. $\mathrm{sp}$.

"Pericyclus fasciculatus Mc Coy" = Goniocyclus sp.

"Pericyclus sp." = Goniocyclus gensoni n. sp.

"Pericyclus niger Delépine" = Nigrocyclus niger (Delépine, 1935)

"Nomismoceras Frechi Schmidt" = Eocanites sp.

"Nomismoceras sp." = Eocanites $\mathrm{sp}$.

"Prolecanites (Protocanites) sp." = Eocanites sp.

'Calcaire de Faugères' (= Faugères Formation); pink and greenish nodular limestones:

"Pericyclus Kochi Holzapfel" = Ammonellipsites kochi (Holzapfel, 1889), A. hauchecornei (Holzapfel, 1889)

"Pericyclus Hauchecornei Holzapfel" = Ammonellipsites hauchecornei (Holzapfel, 1889)

"Pericyclus virgatus de Koninck" = Ammonellipsites hauchecornei (Holzapfel, 1889)

"Pericyclus sp." = Ammonellipsites sp.

"Prolecanites (Merocanites) applanatus Frech" = Merocanites applanatus (Frech, 1899)

"Nomismoceras (?) sp." = Merocanites applanatus (Frech, 1899)

"Beyrichoceras cf. micronotum Phillips" = Dzhaprakoceras sp.

"Beyrichoceras cf. implicatum Phillips" = Winchelloceras sp.

"Glyphioceras cf. Barroisi Holzapfel" = Dzhaprakoceras? sp.

"Goniatites Haan nov. sp." = Dzhaprakoceras sp.

"Goniatites sp." = goniatite indet.

'Schistes du Landeyran' (= upper portion of the Puech Capel Formation); greenish shales with crushed ammonoid specimens:

"Goniatites subcircularis Miller" = Neoglyphioceras sp.

"Sagittoceras sp." = Ferganoceras sp.

'Calcaire a Productus giganteus':

"Goniatites Haan" = Goniatites sp.

The annotated list demonstrates that Böhm's monograph required revision. Particularly the goniatites from the phosphoritic nodules were completely misinterpreted by Böhm, leading him to the wrong conclusion that they have an early Viséan age. A complete revision of all this material is presented herein.

\section{Lithostratigraphic succession}

The Carboniferous sedimentary rock succession of the Montagne Noire is composed of three major lithostratigraphic units, from the upper part of Montagne Noire Griotte Group (of which the majority belongs to the Late Devonian), the SaintNazaire Group, and the Laurens Flysch Group (Feist 1985; Robardet et al. 1994).

\section{Montagne Noire Griotte Group}

At five places in the southeastern Montagne Noire, the Devonian-Carboniferous transitional beds are well exposed with nodular ammonoid-bearing limestones below and above the boundary (Fig. 3):

Puech de la Suque - vineyard road cutting $2 \mathrm{~km}$ southeast of St. Nazaire-de-Ladarez village (Krylatov 1964; Boyer et al. 1968; Vachard 1977; Michel 1981; Brauckmann et al. 1993; Korn 1993; Girard 1994).

Puech Capel - slope in an old vineyard $2.1 \mathrm{~km}$ south-southeast of St. Nazaire-de-Ladarez village.

Col de Tribes - eastern slope of Mont Peyroux.

Pic de Vissous - some trenches $2.3 \mathrm{~km}$ north-northwest of Cabrières.

La Serre - $2.3 \mathrm{~km}$ south of Cabrières; trench E' is the stratotype of the Devonian-Carboniferous Boundary (Flajs \& Feist 1988; Paproth et al. 1991; Brauckmann et al. 1993; Girard 1994; Feist et al. 2000). At this locality, the Devonian-Carboniferous transitional beds are shallow-water deposits with crinoidal grainstones and oolites.

In the first four of these sections, the Carboniferous part of the Griotte (upper part of the 'Calcaire Supra-Griottes'; Lethiers \& Feist 1990) has a thickness of approximately 3 metres. It overlies a shaly layer of 0.30 to $0.60 \mathrm{~m}$ in thickness (most probably an equivalent of the Hangenberg Black Shale in the Rhenish Slate Mountains). It is composed of light to dark grey and often yellowish weathered nodular limestones with thin shaly intercalations. The shaly content increases towards the top of this unit and finally, the limestone nodules become dissociated and isolated within the increasing claystone matrix and subsequently disappear.

At Puech de la Suque, where the conodont succession is well established (Boyer et al. 1968; Girard 1994; Kaiser 2005), the lowest occurrence of Siphonodella sulcata (Huddle) was discovered a few centimetres above the base of the limestone unit, indicating that the Devonian-Carboniferous Boundary probably lies within the limestone sequence. The succession of conodonts shows that all five conodont zones, which are present in the Hangenberg Limestone of the Rhenish Mountains (Upper praesulcata Zone, sulcata Zone, Lower and Upper duplicata Zone, sandbergi Zone), are represented in this section (Girard 1994; Klapper (pers. communication); Kaiser 2005). Although the limestones of the upper part of the Supra-Griotte are considerably rich in macrofossils, only a few sufficiently well preserved faunas have been assembled. This is due to the fact that the brittle limestone allows only rarely an extraction of determinable fossils. From the lowest bed (bed 10) of this rock unit at Puech de la Suque, an ammonoid fauna exclusively composed of Acutimitoceras was collected (Korn 1993); this fauna may represent the latest Devonian Acutimitoceras prorsum Zone. Ammonoids are also known from three higher horizons, indicating most probably their attribution to the Gattendorfia subinvoluta Zone (Fig. 3). 


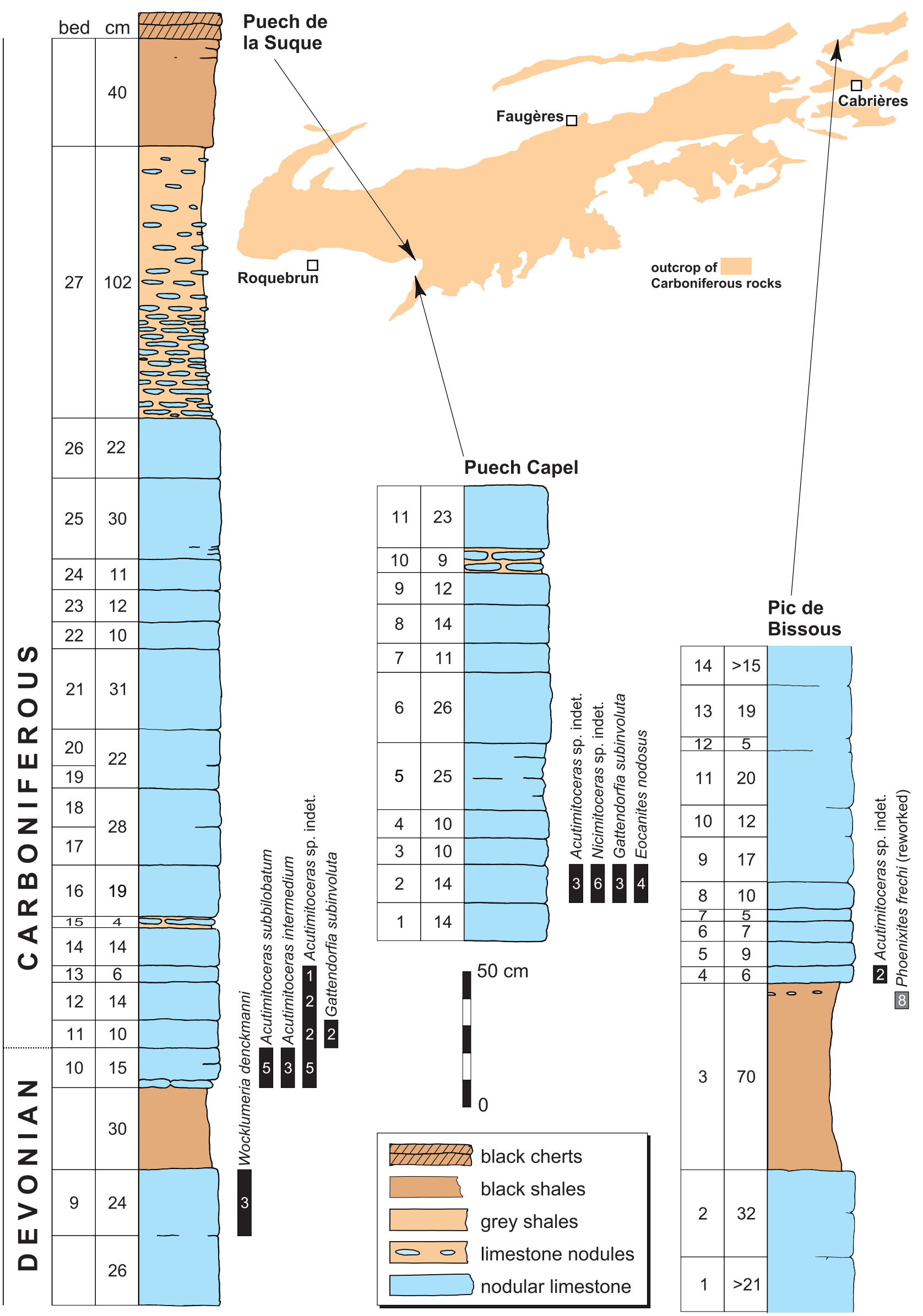

Fig. 3. Devonian-Carboniferous boundary sections in the Montagne Noire and the stratigraphic distribution of ammonoids. 
At Pic de Bissous, the first nodular limestone horizon above the 'Hangenberg Shale' yielded only poorly preserved large ammonoids, which also may belong to the genus Acutimitoceras (Fig. 3). In the body chambers of these large individuals, numerous small ammonoids are preserved, as in bed 10 of the Puech de la Suque section. In the topmost 'Hangenberg Shale', reworked limonitic specimens of the earliest Famennian ammonoid Phoenixites frechi (Wedekind, 1918) were collected.

An assemblage with Gattendorfia subinvoluta (Münster, 1832) and Eocanites nodosus (Schmidt, 1925) was recorded from bed 2 of the section at Puech Capel (Fig. 3). 16 specimens were collected from this brittle nodular limestone horizon, but it was difficult to extract the specimens.

Earliest Carboniferous ammonoids were found at Col de Tribes on the eastern slope of Mont Peyroux (Becker \& Weyer 2004). Although contaminated by associated Devonian elements, there is a true Gattendorfia fauna. Most of the material, however, is poorly preserved and does not allow specific determination (see Korn 2005). The revised fauna (see Fig. 4) consists of the following species (identifications by Becker and Weyer and revised designations):
"Mimimitoceras" hoennense Korn, 1993 = Mimimitoceras hoennense Korn, 1993

Hasselbachia? n. sp. = Mimimitoceras sp.

Stockumites aff. convexus (Vöhringer, 1960) = Acutimitoceratinae indet.

Stockumites subbilobatus (Münster, 1839) = Acutimitoceratinae indet.

Nicimitoceras aff. trochiforme (Vöhringer, 1960) = Acutimitoceras sp.

"Gattendorfia" molaris Vöhringer, $1960=$ Ammonoidea indet.

Globimitoceras globiforme (Vöhringer, 1960) = Globimitoceras globiforme (Vöhringer, 1960)

Paragattendorfia aff. patens (Vöhringer, 1960) $=$ Wocklumeria deuckmanni Wedekind, 1918 (Late Devonian contamination)

Bartzschiceras mirandum Becker \& Weyer, $2004=$ Bartzschiceras mirandum Becker \& Weyer, 2004

Paralytoceras $\mathrm{sp}$. indet. = Bivalvia indet.

Eocanites ruani Bartzsch et al., $2004=$ Eocanites $\mathrm{sp}$.

Eocanites $\mathrm{sp}$. ind. = Eocanites $\mathrm{sp}$.

The section in trench E' at La Serre was intensely studied by Dieter Weyer, and the results were published by Becker \& Weyer (2004). The following faunal spectrum (see Fig. 5) is known from the exposure:

"Mimimitoceras" varicosum (Schindewolf, 1923) = Mimimitoceras sp.

Stockumites sp. ind. = Acutimitoceratinae indet.

"Gattendorfia" aff. discoides Ruan, 1981 = Weyerella sp.

Gattendorfia sp. ind. juv. = Gattendorfia sp.
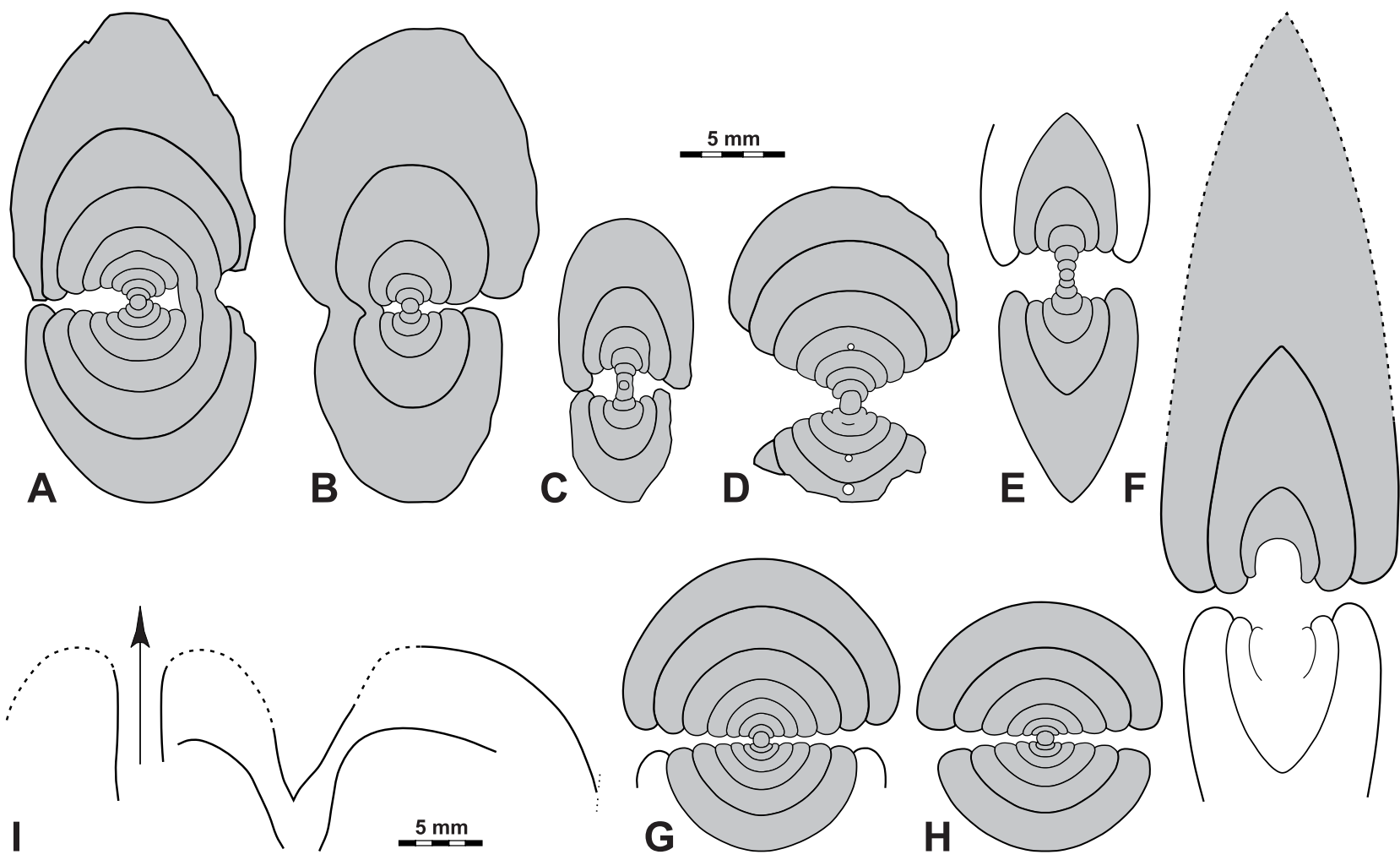

Fig. 4. Cross sections $(\mathrm{A}-\mathrm{H} ; \times 2.5)$ and suture line $(\mathrm{I} ; \times 2)$ of ammonoids from the Devonian-Carboniferous boundary beds at Col de Tribes; all Becker coll. A - Mimimitoceras sp., specimen MB.C.3765 [figured by Becker \& Weyer (2004) as Hasselbachia? n. sp.]. B - Acutimitoceras sp., specimen MB.C.3768.1 [figured by Becker \& Weyer (2004) as Nicimitoceras aff. trochiforme]. C - Nicimitoceras cf. heterolobatum (Vöhringer, 1960), specimen MB.C.3766 [figured by Becker \& Weyer (2004) as Stockumites aff. convexus]. D - Wocklumeria denckmanni Wedekind, 1918, specimen MB.C.3771 [figured by Becker \& Weyer (2004) as Paragattendorfia aff. patens]. E - Bartzschiceras mirandum Becker \& Weyer, 2004, paratype MB.C.3367.3. F - Bartzschiceras mirandum Becker \& Weyer, 2004, paratype MB.C.3367.1. G - Globimitoceras globiforme (Vöhringer, 1960), specimen MB.C.3770.1. H - Globimitoceras globiforme (Vöhringer, 1960), specimen MB.C.3770.2. I - Acutimitoceras sp., specimen MB.C.3768.3; at $43.5 \mathrm{~mm}$ dm [figured by Becker \& Weyer (2004) as Nicimitoceras aff. trochiforme]. 

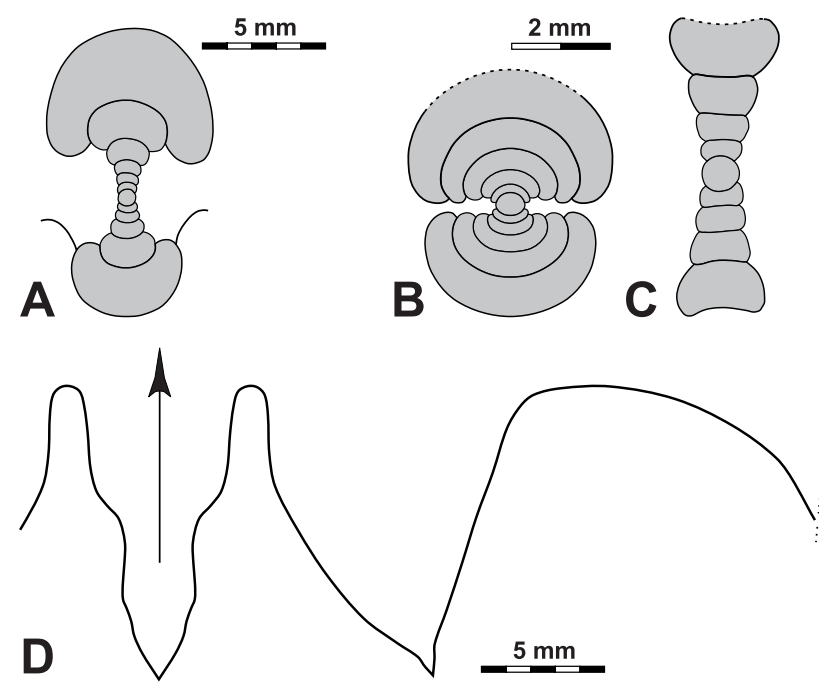

Fig. 5. Cross sections $(\mathrm{A}-\mathrm{C})$ and suture line (D) of ammonoids from the Devonian-Carboniferous boundary beds at La Serre; all Weyer coll. A - Acutimitoceras sp., specimen MB.C.3728 [figured by Becker \& Weyer (2004) as "Gattendorfia" aff. discoides (Ruan, 1981)]; $\times 2.5$. B - Nicimitoceras varicosum (Schindewolf, 1923), specimen MB.C.3726; $\times 5$. C Gattendorfia sp., specimen MB.C.3732 [figured by Becker \& Weyer (2004) as Gattendorfia? sp. juv. aff. ventroplana Schindewolf, 1924]; $\times$ 5. D - Bartzschiceras mirandum Becker \& Weyer, 2004, holotype MB.C.3733, at $26 \mathrm{~mm}$ wh; $\times 2.5$.

Gattendorfia sp. juv. aff. ventroplana Schindewolf, $1924=$ Gattendorfia sp.

Bartzschiceras mirandum Becker \& Weyer, $2004=$ Bartzschiceras mirandum Becker \& Weyer, 2004

Eocanites $\mathrm{sp}$. ind. = Eocanites $\mathrm{sp}$.

A record of a specimen of Acutimitoceras intermedium (Schindewolf, 1923) from bed 90 (dark grey crinoidal limestones; Racheboeuf coll.) is the only well-preserved ammonoid specimen from the shallow-water carbonates of this section.

\section{Saint-Nazaire Group}

The term Saint-Nazaire Formation was introduced by Feist (1985) to include three different rock units: the 'Horizon à lydiennes', the 'Calcaire de Faugères', and the 'Calcaire à Colonnes'. This formation is here raised into a status of a group, with the composing formations being the former members of Feist (1985). Additionally, a newly discovered rock formation is described. In ascending order, here are the following formations within this group:

Lydiennes Formation ('Horizon à lydiennes')

Faugères Formation ('Calcaire de Faugères')

Colonnes Formation ('Calcaire à Colonnes')

Puech Capel Formation (formerly not defined)

Lydiennes Formation - At its type locality on the south-eastern slope of Puech de la Suque hill, the Lydiennes Formation has a thickness of approximately $30 \mathrm{~m}$ and is a rather monotonous succession of thin (2 to $10 \mathrm{~cm}$ thickness of individual beds) black cherts ("lydites"). It closely resembles the lydites of other regions such as the Rhenish Mountains, but contains in its basal part numerous phosphoritic nodules up to $5 \mathrm{~cm}$ in diameter. These have been commercially exploited in the middle of last century for phosphates, and were mined in numerous excavations on the south-eastern slope of the Puech de la Suque. Besides a rich radiolarian content (Deflandre 1946, 1973), the nodules are famous for their permineralised plant remains (e.g., Theron 1899; Böhm 1935b; Genson 1940, 1941; Maurel 1966; Meyer-Berthaud 1984a, 1984b; Galtier et al. 1988; Rowe \& Galtier 1989, 1990), as well as faunas with cephalopods (Blayac et al. 1935a, 1935b; Delépine 1935; Böhm 1935a) and arthropods (Delépine 1935; Böhm 1935a; Rolfe 1985). It was Böhm in particular who collected fossil material from this formation. According to his publication, he employed 15-20 workers to cut more than 100,000 nodules to gather the rich assemblages that he described in his monograph (Böhm 1935a).

The precise stratigraphic position of the 'Horizon à lydiennes' has been long debated. Following the studies by Böhm (1935a), it was first concluded that they were of early Viséan age (Böhm 1936; Delépine 1937). However, revision of the faunal composition including the genera Eocanites, Becanites, Globimitoceras, Gattendorfia, Nigrocyclus, and Goniocyclus does not confirm this age; the fauna closely resembles the composition of the 'middle' to early Late Tournaisian Rußschiefer of Zadelsdorf in Thuringia (Schindewolf 1926a, 1939) and of the Bordalete Formation of the South Portuguese Zone (Korn 1997a). Also the Northview Shale and Chouteau Limestone of Missouri (Miller \& Collinson 1951) and the Wassonville Limestone of Iowa (Furnish \& Manger 1973) contain a fauna with similar elements. In the fauna of the Lydiennes Formation, neither typical elements of latest Tournaisian nor of Viséan age have been detected.

A more similar ammonoid assemblage is known from the Oued Znaïgui Formation of the Tafilalt in Morocco (Korn et al. 2002). This fauna is composed of the genera Goniocyclus, Gattendorfia, Eocanites, and Protocanites, which are partly represented in the fauna of the Lydiennes Formation. Both faunas have a probable 'middle' Tournaisian age. This age is not in conflict with conodonts of the late Tournaisian Scaliognathus anchoralis Zone from the base of the Faugères Formation that lies immediately above the lydites (Engel et al. 1982).

Ammonoid faunas from the phosphoritic nodules are available from the following localities:

"St. Nazaire-de-Ladarez" - (probably outcrops at Puech de la Suque); Böhm, Marrot, Thoral, Vidal coll.

Les Granges - north of Coumiac quarry near Cessenon; Albaille, Genson coll.

Siala near Cessenon; Albaille coll.

Pépus near Cessenon; Albaille coll.

Cabrières - (probably outcrops at Pic de Bissous or La Serre); Böhm coll. 
Faugères Formation - The Faugères Formation is, at Puech de la Suque, an eight metres thick unit of pink or yellowish nodular limestones. The formation is incompletely exposed there, and hence precise data about the distribution of index fossils within this unit do not exist. Coudray et al. (1979), Engel et al. (1982) as well as Lethiers \& Feist (1991) mentioned the conodonts Scaliognathus anchoralis, Doliognathus latus, and Gnathodus pseudosemiglaber from the lower two metres of the formation, which date them latest Tournaisian. Higher samples yielded Gnathodus praebilineatus, Mestognathus beckmanni as well as Pseudopolygnathus homopunctatus which indicate the Early Viséan. This succession also occurs in the localities La Serre, Tourrière, and Escandolgue, all in the vicinity of Cabrières, were Scaliognathus anchoralis is typical for the lower part of the Faugères Formation, while the upper portion is characterised by Mestognathus beckmanni and Pseudopolygnathus homopunctatus (Engel et al. 1982).

Vachard (1977) investigated exposures of the Faugères Formation at Mont Peyroux near Cessenon and at Mont Mou near Faugères, the latter being the type locality of the formation. Based on their foraminiferan content, he postulated a V1b Zone age for the "calcaires noduleux".

The ammonoid fauna of the nodular limestones will be revised in the following account. The assemblage consists of the genera Merocanites, Ammonellipsites, Dzhaprakoceras, and Winchelloceras. This composition resembles assemblages from the Erdbach Limestone of the Rhenish Mountains (Holzapfel 1889) and the Harz (Schindewolf 1951), the Dzhaprykskiy Gorizont in Tyan' Shan' (Popov 1968), and the 'Lower Limestone' of Ireland (Foord 1901, 1903). Similar in lithology and fauna is also the lower portion of the Alba Formation of the Cantabrian Mountains (Kullmann 1961). A latest Tournaisian age of the fauna is most likely; there are no indications for an early Viséan age in terms of current understanding. However, according to Lethiers \& Feist (1991), ammonoids of the genera Merocanites and Ammonellipsites were recorded from the higher portion of the Faugères Member, which, in terms of conodont stratigraphy belong in the Viséan.

Ammonoid faunas from the Faugères Formation are available from the following localities:

Faugères - (quarry at Mont Mou $1 \mathrm{~km}$ south of Faugères); Böhm coll., Korn 1999 coll.

Cabrières - (probably Pic de Bissous); Böhm coll.

"St. Nazaire-de-Ladarez" - (probably outcrops at the Puech de la Suque); Böhm coll.

Escandolgue -near Cabrières; Feist and Franke coll.

La Tourière - $1.75 \mathrm{~km}$ west-southwest of Cabrières; Feist coll. Péret $-2 \mathrm{~km}$ east of Cabrières

Colonnes Formation - The Colonnes Formation ("Calcaire à colonnes", auct.) is an approximately 30 to 50 metres thick succession of fine- to coarse-grained limestone turbidites alternating with thin light coloured chert and shaly intercalations. It is very poor in macrofossils, and not a single ammonoid specimen was found in this rock unit.

Puech Capel Formation (new) - Preceding the base of the siliciclastic flysch complex more than $100 \mathrm{~m}$ of olistostrome-like coarse debris flow deposits are accumulated incorporating pluri-decimetric blocks of shallow-water limestones. ('schistes troués' of Engel et al. 1982). These deposits are overlain by approximately $20 \mathrm{~m}$ of greenish shales with intercalated marly nodular limestone beds of 5 to $20 \mathrm{~cm}$ thickness that characterize the upper part of the Formation. A third Early Carboniferous 'griotte' in the Montagne Noire was known from a locality north of Roquebrun (W. Franke, pers. comm.) and is described here for the first time. Time equivalent nodular limestones are well-known from the Cantabrian Mountains (higher portion of the Alba or Genicera Formation) and also from the Massif de Mouthoumet and the Pyrenees (Bessière et al. 1980; Colmenero et al. 2002).

The newly described formation resembles the Early Tournaisian Griotte, but contains only a sparse ammonoid fauna with Dombarites granofalcatus (Kullmann, 1961) and Irinoceras sp. A conodont sample from the ammonoid-bearing horizon yielded non-specific conodonts with Gnathodus bilineatus. According to the ammonoids, a latest Viséan age is most likely. Ammonoids come from two localities:

Puech Capel - $2.4 \mathrm{~km}$ south-southeast of St. Nazaire-deLadarez. Three-dimensionally preserved ammonoid specimens were collected in the basal, calcareous portion of the formation; Korn 1999 coll.

Northeastern slope of Puech de la Suque - $1.5 \mathrm{~km}$ eastsoutheast of St. Nazaire-de-Ladarez. One three-dimensionally preserved specimen of Neogoniatites canovasi n. sp. from a nodule within the topmost, shaly portion of the formation is available; Canovas coll.

Above the nodular limestones, the section continues with greenish shales with thin marly intercalations ('Schistes du Landeyran' according to Böhm 1935a), in which Böhm identified the species "Goniatites subcircularis Miller" = Neoglyphioceras sp. and "Sagittoceras sp." = Ferganoceras sp.

The age of the fauna is, according to the ammonoid species, most likely latest Viséan. The only locality is:

Landeyran valley near Causses-et-Veyran (crushed ammonoid specimens from the upper, shaly portion of the formation); Guiraud coll.

\section{Laurens Flysch Group}

Index fossils from the flysch deposits have rarely been discovered, and hence stratigraphic interpretation is extremely difficult. The goniatites, which Böhm probably has assembled after publication of his monograph, are most useful for an precise age determination of the Flysch. Further specimens have been discovered during mapping of the Flysch series (Engel et al. 1978, 1982). Although crushed 
in shales and not very well preserved, these specimens are obviously conspecific with the single specimen from the underlying Puech Capel Formation of Puech de la Suque and allow their assignment to Neogoniatites. This genus is not known from Carboniferous successions of Central and Northwestern Europe (Korn 1997b), but occurs rather frequently in the South Urals and in North Africa (Korn et al. 1999; Korn \& Ebbighausen in Klug et al. 2006). In the South Urals it is a component of a rich ammonoid fauna (Ruzhencev \& Bogoslovskaya 1971), which contains numerous taxa not known from the northern flank of the Variscides. The discovery of Neogoniatites in the Montagne Noire can be regarded as an indication for a close relationship to the South Uralian and North African faunal provinces, rather than to the Subvariscan province (Korn 1997b; Korn et al. 1999).

Neogoniatites is a genus that, according to $\mathrm{Ru}-$ zhencev \& Bogoslovskaya (1971), is restricted to their Nm1a Zone (which is regarded as the basal zone of the Namurian stage by these authors). The absence of Lusitanoceras (which has been replaced by Dombarites) in this zone, the presence of Lyrogoniatites plus the position below the appearance of the genus Cravenoceras allow a correlation of the Nm1a Zone with the youngest Late Viséan (Lyrogoniatites liethensis Zone to Emstites novalis Zone) of the Rhenish Mountains and neighbouring areas (Korn 1996). This means that deposition of the lowest part of the Flysch ("part I" in Engel et al. 1991) most probably occurred within the duration of only one goniatite zone within the latest Viséan. The occurrence of plant remains with affinities to Namurian floras in the highest Flysch near Cabrières (Feist \& Galtier 1985) does not contradict this age interpretation.

Ammonoid faunas from the basal Flysch are available from the following localities:

'St. Nazaire-de-Ladarez' - (probably outcrops at the Croix de Barrac); Böhm coll.

Croix de Barrac $-0.7 \mathrm{~km}$ east of St. Nazaire-de-Ladarez; Marrot coll.

Barrac valley $-2 \mathrm{~km}$ east of St. Nazaire-de-Ladarez; Engel and Franke coll.

Domaine de Barrac - $3.7 \mathrm{~km}$ east of St. Nazaire-de-Ladarez; Engel and Franke coll.

\section{Palaeontological descriptions}

Descriptive terms of the conch features are adopted from Korn (1988); abbreviations of the conch dimensions are:

conch diameter $(\mathrm{dm})$

whorl width (ww)

whorl height (wh)

umbilical width (uw)

aperture height (ah)

The whorl expansion rate (WER) is calculated: WER $=[\mathrm{dm} /$ $(\mathrm{dm}-\mathrm{ah})]^{2}$. The imprint zone rate (IZR) is the ratio that characterises the whorl overlap; it is calculated: $\mathrm{IZR}=(\mathrm{wh}-\mathrm{ah}) / \mathrm{wh}$.
The material described and figured in the following account is stored in the collections of the Institut des Sciences de l'Evolution, Université Montpellier II (UMC-IP prefix) and the Museum für Naturkunde der Humboldt-Universität zu Berlin (MB.C. prefix).

\section{Montagne Noire Griotte Formation}

Family Prionoceratidae Hyatt 1884

\section{Acutimitoceras Librovitch, 1957}

\section{Acutimitoceras subbilobatum (Münster, 1839)}

Fig. 6A

Material. Five specimens between 16 and $29 \mathrm{~mm}$ conch diameter are available from bed 10 of the section at Puech de la Suque (MB.C.9420.1-5; Korn 1990 coll.).

Description. The specimens are corroded internal moulds, but show the characters typical for the species, e.g. the discoidal conch shape with almost parallel flanks, the rounded venter, the almost linear steinkern constrictions on the flank, and the suture line with an asymmetric adventive lobe and a deep, lanceolate external lobe.

\section{Acutimitoceras intermedium (Schindewolf, 1923)}

Fig. 6B, C, H

Material. Three rather poorly preserved corroded steinkern specimens between 36 and $60 \mathrm{~mm}$ conch diameter from bed 10 of the section at Puech de la Suque (MB.C.9421.1-3; Korn 1990 coll.). One well-preserved specimen MB.C.9428 (Racheboeuf coll.) with approximately $42 \mathrm{~mm}$ conch diameter is available from the oolites of La Serre section (Fig. 6H).

Description. The specimen from La Serre has a thickly discoidal conch $(\mathrm{ww} / \mathrm{dm}=0.53)$ without constrictions. It is a fully septate steinkern with attached shell remains. The suture line has a deep and lanceolate external lobe, a wide ventrolateral saddle, and a narrow and asymmetric adventive lobe with an inflexed dorsal flank. Growth lines of the specimen are lamellar, and extend in a convex course across the flanks. On the venter, they form a shallow, slightly angular sinus. Remains of the growth lines can not be seen on the steinkern, but periodical and narrowly arranged short constrictions are visible on the inner flank; they cause a feeble ribbing.

\section{Nicimitoceras Korn, 1993}

\section{Nicimitoceras sp. 1}

Figs 6D, 7

Material. Six specimens from bed 2 of Puech Capel section (MB.C.9425.1-6; Korn 1999 coll.); they range in their size from 15 to $45 \mathrm{~mm}$ conch diameter. 

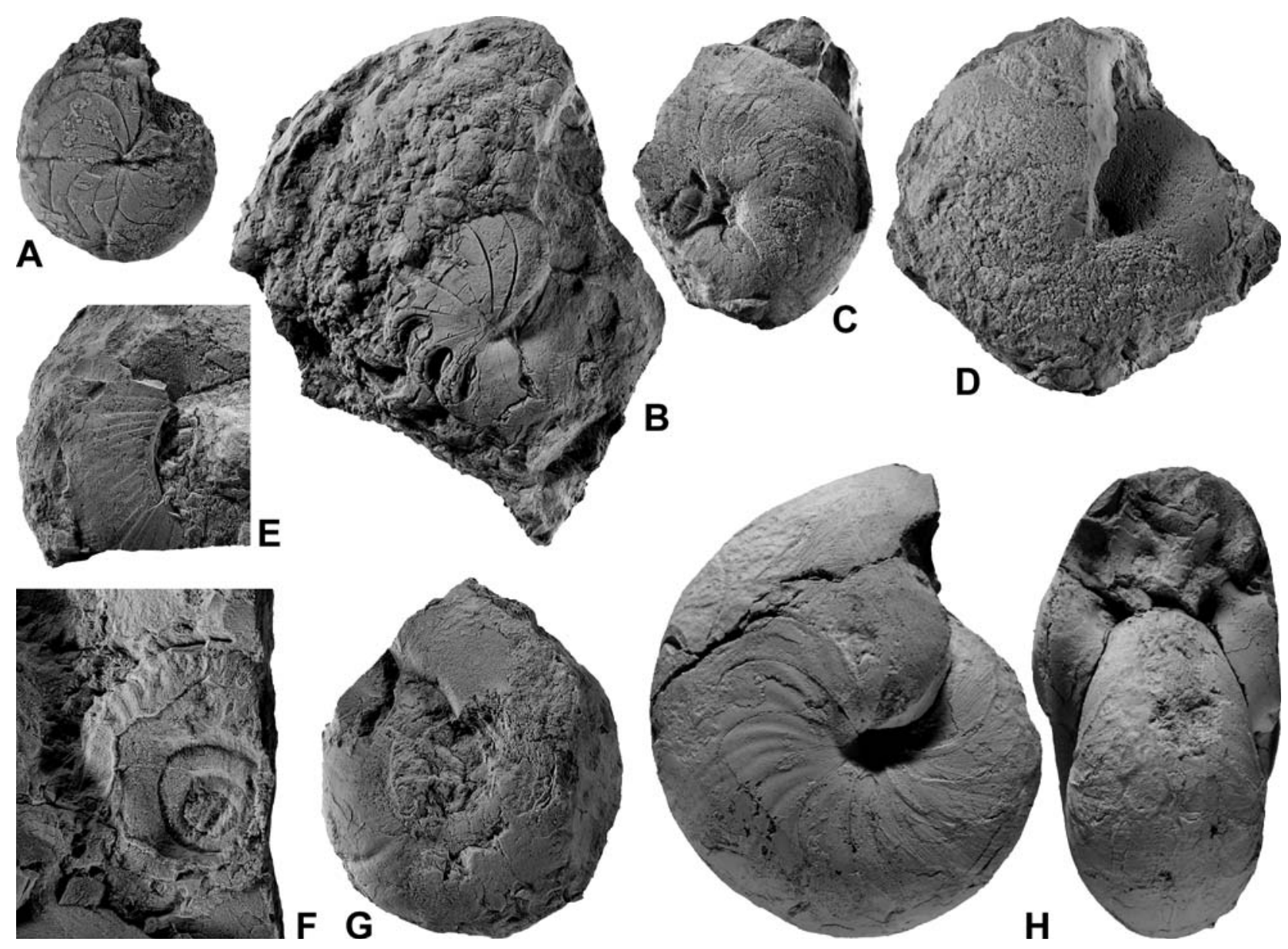

Fig. 6. Ammonoids from the upper portion of the Montagne Noire Griotte Group. A - Acutimitoceras subbilobatum (Münster, 1839), specimen MB.C.9420.1 (Korn 1990 coll.) from bed 10 of the Puech de la Suque section, lateral view; $\times 1.5$. B - Acutimitoceras intermedium (Schindewolf, 1923) with numerous small bivalves in the body chamber, specimen MB.C.9421.1 (Korn 1990 coll.) from bed 10 of the Puech de la Suque section, lateral view; $\times 1$. C - Acutimitoceras intermedium (Schindewolf, 1923), specimen MB.C.9421.2 (Korn 1990 coll.) from bed 10 of the Puech de la Suque section, lateral view; $\times 1$. D - Nicimitoceras sp. 1, specimen MB.C.9425.1 (Korn 1999 coll.) from bed 2 of the Puech Capel section, lateral view; $\times 1$. E - Gattendorfia subinvoluta (Münster, 1832), specimen MB.C.9426.1 (Korn 1999 coll.) from bed 2 of the Puech Capel section, lateral view; $\times 1$. F - Eocanites nodosus (Schmidt, 1925), specimen MB.C.9427.1 (Korn 1999 coll.) from bed 2 of the Puech Capel section, lateral view; × 1. G - Gattendorfia subinvoluta (Münster, 1832), specimen MB.C.9426.2 (Korn 1999 coll.) from bed 2 of the Puech Capel section, lateral view; $\times 1$. H - Acutimitoceras intermedium (Schindewolf, 1923), specimen MB.C.9428 (Rachebeouf coll.) from bed 90 of trench E' at La Serre, lateral and dorsal views; $\times 1.5$.

Description. Two cross sections (MB.C.9425.2, MB.C.9425.3) were produced for the investigation of the ontogenetic development of conch morphology. They show somewhat distorted sections caused by tectonic deformation. The ontogeny is characteristic for acutimitoceratids with a widely umbilicate initial stage, which in the described material, is less evolute than typical for Acutimitoceras. The conch is pachyconic in stages smaller than $10 \mathrm{~mm}$ diameter, and thickly discoidal in larger stages. The whorls are thickest near the broadly rounded umbilical margin from where they converge towards the rounded venter. The shell is only very weakly ornamented. None of the specimens possesses steinkern constrictions.

Fragments of the suture line can be seen in specimen MB.C.9425.1 at a conch diameter of approximately $27 \mathrm{~mm}$. Only the slightly asymmetric Vshaped adventive lobe and the very wide dorsolat- eral saddle is visible. The ventrolateral saddle is very narrow.

Discussion. The taxon here presented in open nomenclature probably belongs to the same species as most of the material called "Nicimitoceras trochiforme" by Becker \& Weyer (2004). It is too poorly preserved for a precise determination.

\section{Gattendorfia Schindewolf, 1920}

\section{Gattendorfia subinvoluta (Münster, 1832)}

Fig. 6E, G

Material. Three distorted specimens from bed 2 of Puech Capel section, 30 to $70 \mathrm{~mm}$ in conch diameter (MB.C.9426.1-3; Korn 1999 coll.), and two specimens from bed 11 of Puech de la Suque (MB.C.9423.1-2; Korn 1990 coll.). 


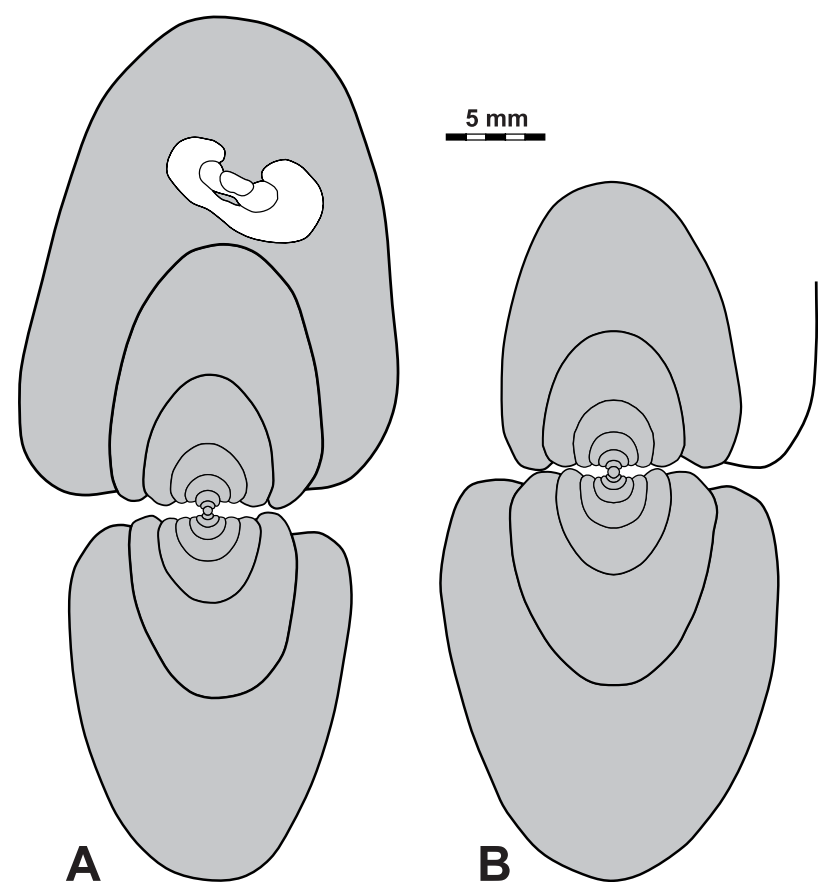

Fig. 7. Cross sections of Nicimitoceras sp. 1 from Puech Capel; $\times 2$. A -specimen MB.C.9425.2 (Korn 1999 coll. ). B - specimen MB.C.9425.3 (Korn 1999 coll.).

Description. The figured specimen MB.C. 9426.2 has, at $40 \mathrm{~mm}$ conch diameter, a rounded umbilical wall from which lamellar growth lines run backwardly across the flanks. A shallow steinkern constriction is visible; it runs parallel with the growth lines and forms a moderately deep external sinus. The small specimen MB.C.9426.3 displays relatively coarse, sharp growth lines, which form a shallow lateral sinus and a deep external sinus. One shell constriction extends parallel to the growth lines.

Family Prolecanitidae Hyatt, 1884

\section{Eocanites Librovitch, 1957}

\section{Eocanites nodosus (Schmidt, 1925)}

Fig. 6F

v 1925 Gattendorfia nodosa Schmidt: 536, pl.19: fig. 10, pl. 23: figs 2, 3 .

v 1960 Protocanites nodosus. - Vöhringer: 169, pl. 6: fig. 1.

v 1994 Eocanites nodosus. - Korn: 81, figs 73A, B, D, 74A, $75 \mathrm{C}$.

Material. Four specimens from Puech Capel, in which growth stages from 15 to $25 \mathrm{~mm}$ conch diameter are represented (MB.C.9427.1-4; Korn 1999 coll.).

Description. The specimens are not well-preserved, but display ornament details that allow specific assignment. The earlier whorls show coarse growth lines which extend in a backward rursiradiate direction across the flanks. Specimen MB.C.9427.1 possesses ventrolateral ribs at $25 \mathrm{~mm}$ conch diameter (Fig. 6F).

\section{Lydiennes Formation}

Family Prionoceratidae Hyatt, 1884

\section{Globimitoceras Korn, 1993}

\section{Globimitoceras albaillei n. sp.} Figs $8 \mathrm{D}-\mathrm{H}, 9$

1935 Aganides sp. Delépine: 66, pl. 1: figs 1, 2.

v 1935a Aganides ornatissimus. - Böhm: 98, pl. 3: figs 1-3.

Derivation of name. After the private collector Albaille, who contributed much to the knowledge of Palaeozoic ammonoids from the Montagne Noire.

Holotype. Specimen UMC-IP 605 (Vidal coll.), illustrated here in Fig. 8D.

Type locality and horizon. St. Nazaire-de-Ladarez (Montagne Noire); phosphoritic nodules within the Puech de la Suque Formation ('middle' Tournaisian).

Mate rial. 22 specimens (Böhm, Albaille, Thoral, Vidal, and Korn collections), which allow the study of growth stages from very small individuals of a few millimetres up to $35 \mathrm{~mm}$ in diameter. Most specimens are preserved as hollow forms in the siliceous nodules, of which some allowed to produce latex casts. Only few specimens are three-dimensionally preserved.

Diagnosis. Species of Globimitoceras with globular conch at $5 \mathrm{~mm}$ conch diameter $(\mathrm{ww} / \mathrm{dm}=0.90)$, decreasing to a pachyconic conch at $20 \mathrm{~mm} \mathrm{dm}(\mathrm{ww} / \mathrm{dm}=0.70)$. Umbilicus in the initial stage moderately narrow (uw/dm 0.25), rapidly closing during early ontogeny and completely closed at $8 \mathrm{~mm}$ conch diameter. Suture line with asymmetric, lanceolate and very narrow adventive lobe that is deeper than the external lobe. Ornament with fine convex growth lines; shallow steinkern constrictions.

Description. The cross section of paratype UMC-IP 603 (Fig. 9A) displays eight volutions, in which several morphological trends are observable. The relative thickness of the conch decreases continuously; the early whorls are almost spindle-shaped $(\mathrm{ww} / \mathrm{dm}=1.05-1.10)$, globular at $3.5 \mathrm{~mm}$ diameter, and pachyconic with a ww/dm ratio of 0.73 at $20 \mathrm{~mm}$ diameter. The umbilicus is opened in the earliest whorls (uw/dm is maximally 0.25 ), but it is almost completely closed in stages above $5 \mathrm{~mm}$ conch diameter. The conch has always a low aperture, and throughout ontogeny, the whorl spiral opens in a similar rate with a whorl expansion rate that is slightly reduced from 1.65 in early whorls to 1.60 at $20 \mathrm{~mm}$. All whorls show broadly rounded flanks, a rounded umbilical margin, and a broad venter.

Specimen UMC-IP 605 was chosen as holotype. It is the specimen figured by Böhm (1935a, pl. 3: fig. 2) and is now free of matrix by using hydrochloric acid. It is a siliceous steinkern specimen of $24 \mathrm{~mm}$ diameter, which is thickly discoidal (ww/dm $=0.75$ ) with a closed umbilicus. Flanks and venter are broadly rounded. The steinkern shows one shallow, convex constriction that is deepest on the inner flank. The suture line of the holotype has a 

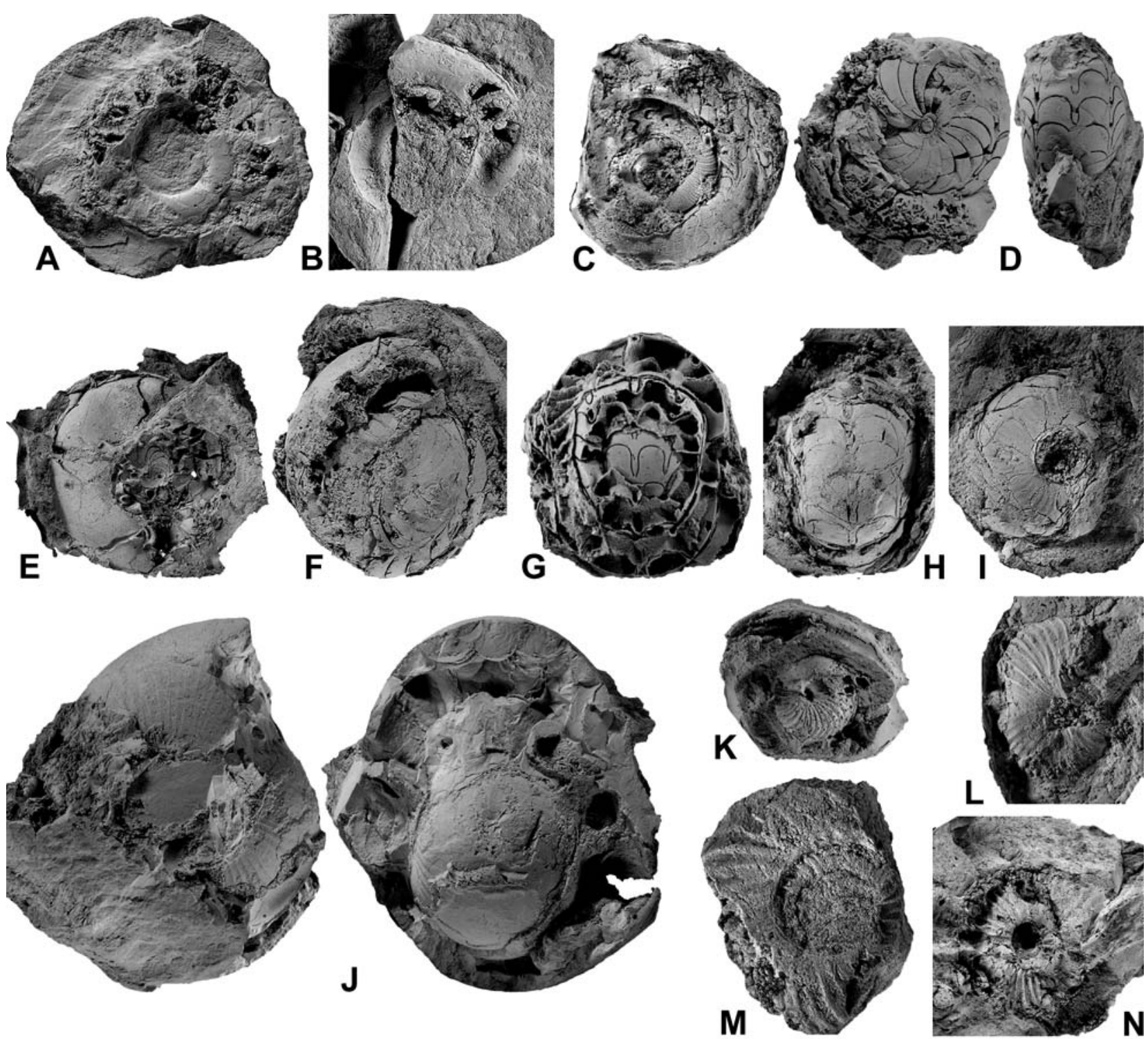

Fig. 8. Ammonoids from the Lydiennes Formation. A - Eocanites sp., specimen UMC-IP 635 (Böhm coll.) from St. Nazaire-deLadarez, lateral view; $\times 1.25$. B - Eocanites sp., specimen UMC-IP 637 (Böhm coll.) from St. Nazaire-de-Ladarez, lateral view; $\times$ 1.25. C - Becanites sp., specimen UMC-IP 639 (Albaille coll.) from Les Granges, lateral view of a latex cast; $\times 1.5$. D - Globimitoceras albaillei n. sp., holotype UMC-IP 605 (Vidal coll.) from St. Nazaire-de-Ladarez, lateral view; $\times 1$. E - Globimitoceras albaillei $\mathrm{n}$. sp., paratype UMC-IP 604 (Thoral coll.) from St. Nazaire-de-Ladarez, lateral view of a latex cast; $\times 1$. F - Globimitoceras albaillei n. sp., paratype UMC-IP 609 (Albaille coll.) from Siala, lateral view of a latex cast; $\times 1$. G - Globimitoceras albaillei n. sp., paratype MB.C.9437 (Korn 1999 coll.) from Puech de la Suque, ventral view; $\times 1.5$. H - Globimitoceras albaillei $\mathrm{n}$. sp., paratype UMC-IP 623 (Böhm coll.) from St. Nazaire-de-Ladarez, ventral view of a latex cast; $\times 1$. I - Gattendorfia nazairensis n. sp., paratype UMC-IP 592 (Böhm coll.) from St. Nazaire-de-Ladarez, lateral view of a latex cast; $\times 1$. J - Gattendorfia nazairensis n. sp., holotype UMC-IP 591 (Böhm coll.) from St. Nazaire-de-Ladarez, lateral and dorsalviews; $\times 1$ K - Nigrocyclus niger (Delépine, 1935), specimen UMC-IP 626 (Böhm coll.) from St. Nazaire-de-Ladarez, lateral view of a latex cast; $\times 1.5$. L - Nigrocyclus niger (Delépine, 1935), specimen UMC-IP 628 (Böhm coll.) from St. Nazaire-de-Ladarez, lateral view of a latex cast; $\times 1.5$. M - Goniocyclus sp., specimen UMC-IP 634 (Böhm coll.) from St. Nazaire-de-Ladarez, lateral view; $\times 1.5$. N - Goniocyclus sp., specimen UMC-IP 632 (Genson coll.) from Les Granges, lateral view of a latex cast; $\times 1$.

very narrow lanceolate external lobe that is only two thirds as deep as the adventive lobe, which is also very narrow and lanceolate. A rather wide, broadly rounded saddle connects the two lobes (Fig. 9B).

Paratype UMC-IP 609 shows the external suture line at a diameter of about $26 \mathrm{~mm}$ (Fig. 9B). The external lobe has a lanceolate shape with slightly diverging, sinuous flanks and possesses a mammi- form base. A broad and slightly asymmetric ventrolateral saddle follows, but the most characteristic sutural element is the extremely narrow adventive lobe. Its shape is lanceolate, asymmetric with a steep and almost linear ventral flank and a sinuous dorsal flank. This adventive lobe is much narrower than the external lobe. Towards the umbilicus, a wide and broadly rounded dorsolateral saddle follows, which is almost as high as the ventrolateral 

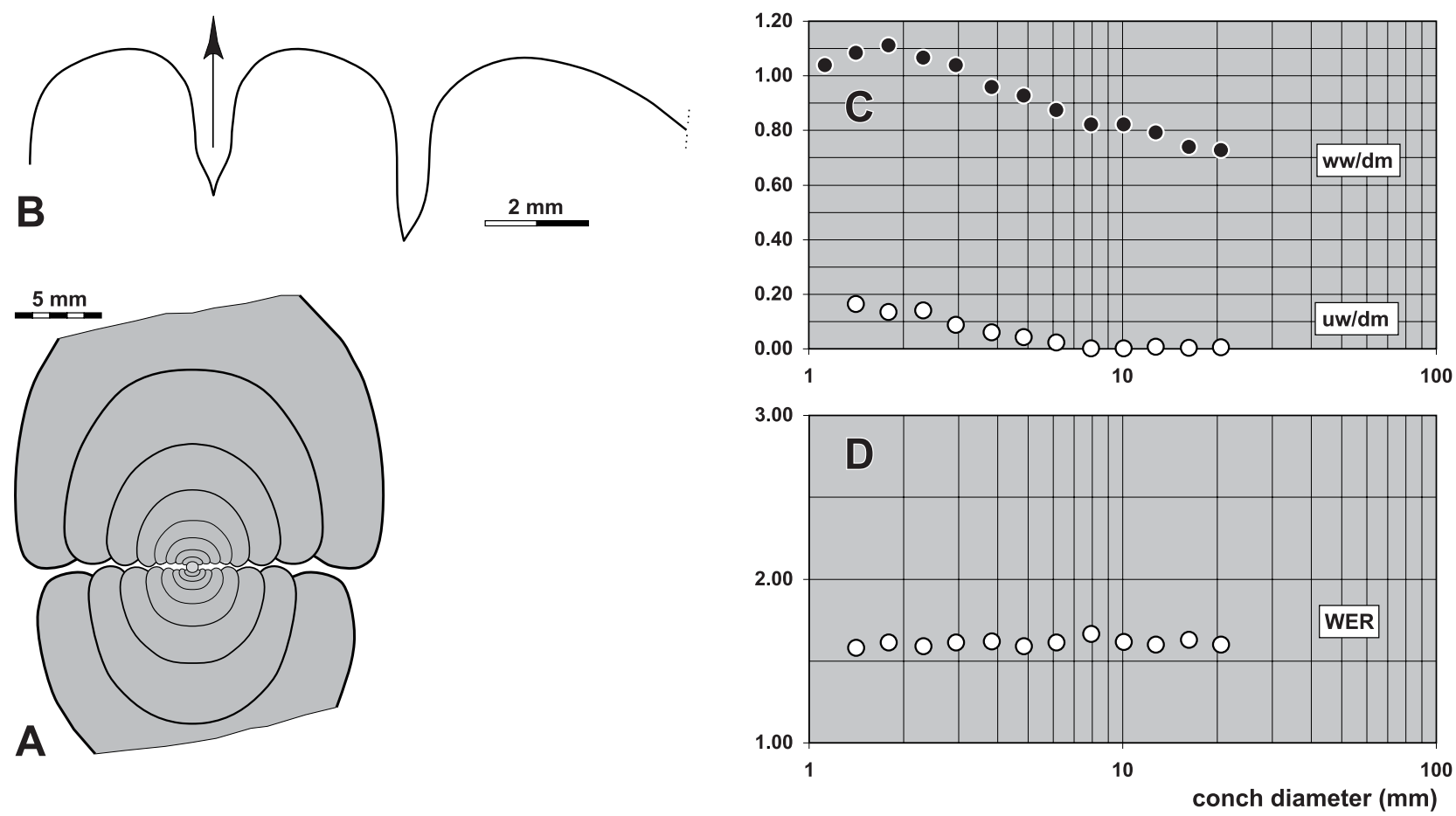

Fig. 9. Globimitoceras albaillei n. sp. A - cross section of paratype UMC-IP 603 (Albaille coll.) from Siala; $\times 2$. B - suture line of UMC-IP 609, at ca. $26 \mathrm{~mm} \mathrm{dm}$, ca. $15.0 \mathrm{~mm} \mathrm{wh} ; \times 6$. C - ontogenetic development of the conch width index (ww/dm) and umbilical width index (uw/dm) in specimen UMC-IP 603. D - Ontogenetic development of the whorl expansion rate (WER) in specimen UMC-IP 603.

saddle. The internal suture line is displayed in paratype UMC-IP 610 at a diameter of $12 \mathrm{~mm}$. This suture line reflects, in the shape of its elements, the external suture, showing very narrow and lanceolate umbilical and internal lobes.

None of the specimens display well preserved ornament details. Only some individuals, such as paratype UMC-IP 604, show that the shell surface is almost completely smooth; growth lines are extremely fine and barely visible. The steinkern is smooth without constrictions.

Discussion. Globimitoceras albaillei differs from many other species of the family Prionoceratidae in its extremely narrow adventive lobe. Globimitoceras globiforme (Vöhringer, 1960) and G. globoidale (Ruan, 1981), which closely resemble each other and differ only in their suture lines, show a more globular conch at comparable growth stages $(\mathrm{ww} / \mathrm{dm}=0.95-1.00$ at $20 \mathrm{~mm} \mathrm{dm})$ than G. albaillei $(\mathrm{ww} / \mathrm{dm}=0.75)$.

\section{Gattendorfia Schindewolf, 1920}

Discussion. The genus Zadelsforfia with its type Gattendorfia asiatica Librovitch, 1940 was erected by Weyer (1972) for gattendorfiid ammonoids with a pouched external lobe. At that time, it appeared to be a clear character to separate Zadelsdorfia from Gattendorfia, but in the meantime, character- istic species of Gattendorfia, such as G. crassa, have been described with a pouched external lobe (Korn 1994; Bockwinkel \& Ebbighausen 2006). Therefore, this character is here regarded as not relevant for a separation of the two genera and Zadelsdorfia is thus a synonym of Gattendorfia.

\section{Gattendorfia nazairensis n. sp.}

Figs 8I, J, 10

v pt 1935a Pericyclus Kochi. - Böhm: 100, pl. 3: figs 4, 5, pl. 4: figs 6, 7 [only].

v pt 1935a Pericyclus Hauchecornei. - Böhm: 102, pl. 3: Fig. 6 [only].

v pt 1935a Pericyclus fasciculatus. - Böhm: 104, pl. 4: figs 4, 6, 7 [only].

Derivation of name. After St. Nazaire-de-Ladarez, where the type material was collected.

Holotype. Specimen UMC-IP 591 (Böhm coll.), illustrated here in Fig. 8J.

Type locality and horizon. St. Nazaire-de-Ladarez (Montagne Noire); Puech de la Suque Formation ('middle' Tournaisian)

Material. 12 specimens of 20 to $48 \mathrm{~mm}$ in diameter. Most of them are preserved as hollow forms, and only the largest specimen, the holotype, is three-dimensionally preserved. The description is based on the holotype as well as paratypes UMC-IP 592 and UMC-IP 593.

Diagnosis. Species of Gattendorfia with pachyconic conch $(\mathrm{ww} / \mathrm{dm}=0.80)$ and a moderately narrow umbilicus (uw/dm ca. 0.20). Umbilical margin narrowly rounded, umbilical wall 


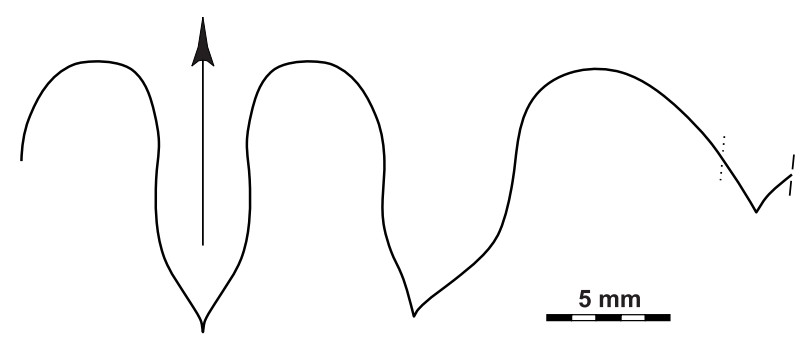

Fig. 10. Gattendorfia nazairensis n. sp., suture line of holotype UMC-IP 593 (Böhm coll.) from St. Nazaire-de-Ladarez, at $35.5 \mathrm{~mm}$ dm, ca. $32 \mathrm{~mm}$ ww, $19.0 \mathrm{~mm}$ wh; $\times 2.5$.

steep. Ornament with 40 riblets per volution, which are restricted to the dorsolateral area. Suture line with slightly pouched external lobe and wide, asymmetric adventive lobe.

Description. The conch shape is best visible in the holotype UMC-IP 591, where the conch measurements listed in the appendix were obtained. The conch is widest near the margin of the umbilicus, which is covered by siliceous matrix in this specimen; this circumstance also prevented the precise measurement of the umbilical width. Flanks and venter are broadly rounded. Shallow riblets are visible on the shell surface on the inner half of the flanks. They have distances of $1.5 \mathrm{~mm}$ and slowly wedge out towards the outer flanks. They are weakly projected near the umbilicus and form a low and widely convex projection on the flanks. Some growth lines are barely visible on the venter, there is a wide and shallow sinus.

The smaller paratypes UMC-IP 592 and UMC-IP 593 confirm the conch and ornament characteristics of the holotype and add the information that the umbilical shoulder is narrowly rounded, and that the umbilical wall is steep. Specimen UMC-IP 592 displays, at approximately $25 \mathrm{~mm}$ diameter, 20 riblets per half volution and demonstrates that they are coarser developed in smaller individuals.

The suture line (Fig. 10) is displayed in paratype UMC-IP 593, where a lanceolate and slightly pouched external lobe is visible at a conch diameter of $35 \mathrm{~mm}$. The adventive lobe is deep and asymmetric. Its ventral flank is steep and gently sinuous, whereas its dorsal flank is strongly inflexed dorsally. This adventive lobe is wider than the external lobe and a little narrower than the almost symmetric, widely rounded ventrolateral saddle. The dorsolateral saddle is asymmetric, and a small $\mathrm{V}$-shaped lateral lobe is located on the umbilical wall.

Discussion. The new species differs especially in its coarse ornament with rectiradiate riblets from the other species of the genus. In the suture line, there is a close resemblance with the Kazakhian species $G$. asiatica Librovitch, 1940, but this species has a much thinner conch (ww/dm less than 0.50 in specimens larger than $25 \mathrm{~mm} \mathrm{dm}$ ) than G. nazairensis.
Family Prolecanitidae Hyatt, 1884

\section{Eocanites Librovitch, 1957}

\section{Eocanites sp.}

Figs 8A, B, 11A, B

1935 Merocanites sp. Delépine: 67, pl. 1: fig. 4.

v 1935a Nomismoceras Frechi. - Böhm: 108, pl. 4: fig. 8.

v 1935a Nomismoceras sp. Böhm: 109.

v 1935a Prolecanites (Protocanites) sp. Böhm: 109, pl. 4: fig. 9.

Material. Three specimens (UMC-IP 635-637; Böhm coll.) between 15 and $37 \mathrm{~mm}$ in diameter. All are imperfectly preserved, being crushed to different degrees, and do not allow to measure conch parameters. Parts of suture lines are preserved in two of the specimens.

Description. The inner whorls of the specimen UMC-IP 636 have, at $15 \mathrm{~mm}$ diameter, an almost circular cross section and an umbilicus that is approximately half of the conch diameter. Larger growth stages, as displayed in specimens UMC-IP 635 and UMC-IP 637, show a slight modification towards higher, oval-shaped whorls at 20 to $25 \mathrm{~mm}$ diameter. Specimen UMC-IP 635 shows, at $16 \mathrm{~mm}$ diameter, the suture line on the flanks (Fig. 11B). It has a deep, lanceolate and pointed adventive lobe and a half as deep, asymmetrically V-shaped lateral lobe. Both are separated by a rounded, inflated saddle. In specimen UMC-IP 637, the suture line is visible at $22 \mathrm{~mm}$ diameter, showing a lanceolate and cuneiform adventive lobe and a small V-shaped lateral lobe (Fig. 11A). The ornament appears to be smooth in the juvenile stage, but specimen UMC-IP 635 displays rather coarse rursiradiate growth lines on the last volution at approximately $35 \mathrm{~mm}$ conch diameter.

\section{Becanites Korn, 1997}

\section{Becanites? sp.}

Figs $8 \mathrm{C}, 11 \mathrm{C}$

Material. One specimen (UMC-IP 638; Böhm coll.) with $14 \mathrm{~mm}$ conch diameter from St. Nazaire-de-Ladarez and one specimen with $24 \mathrm{~mm}$ from Les Granges (UMC-IP 639; Albaille coll.).

Description. Both specimens are rather poorly preserved, the smaller one being corroded and the larger one is a hollow form of which the figured latex cast was made. The whorl cross section is

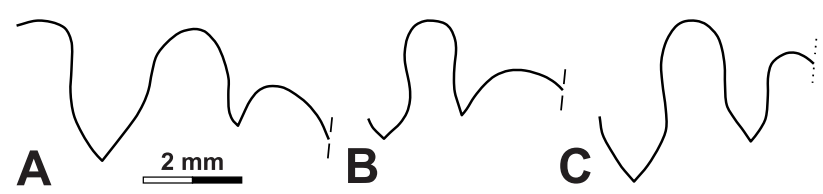

Fig. 11. A - Eocanites sp., suture line fragment of specimen UMC-IP 637 (Böhm coll.) from St. Nazaire-de-Ladarez, at ca. $7 \mathrm{~mm}$ wh; $\times 5$. B - Eocanites sp., suture line fragment of specimen UMC-IP 635 (Böhm coll.) from St. Nazaire-de-Ladarez, at ca. $6 \mathrm{~mm}$ wh; $\times 5$. C - Becanites sp., suture line fragment of specimen UMC-IP 639 (Albaille coll.) from Les Granges, at ca. $8 \mathrm{~mm} w \mathrm{wh} \times 5$. 
almost circular in the smaller specimen UMC-IP 638, and the umbilicus has approximately half of the conch diameter. Both specimens display coarse biconvex growth lines. The suture line of the larger specimen UMC-IP 639 shows two lanceolate lobes on the flank (Fig. 11C). In the smaller specimen, a lanceolate external lobe can be seen and allows an attribution to Becanites.

Family Pericyclidae Hyatt, 1900

\section{Goniocyclus Gordon, 1986}

\section{Goniocyclus sp.}

Fig. 8M, N

v pt 1935a Pericyclus fasciculatus. - Böhm: 104, pl. 4: figs 1, 2 [only]

Material. Three specimens, all of the same size of approximately $25 \mathrm{~mm}$ in diameter, collected by Böhm and Genson. Only UMC-IP 634 is preserved as a three-dimensional mould, the others (UMC-IP 632, UMC-IP 633) are hollow forms.

Description. Specimen UMC-IP 634 shows the following approximated conch ratios: $\mathrm{ww} / \mathrm{dm}=0.44$, $\mathrm{ww} / \mathrm{wh}=1.22$, and $\mathrm{uw} / \mathrm{dm}=0.37$. Flanks and venter are widely rounded, and the umbilical margin is subangular with a steep umbilical wall. The sculpture, which is not well preserved in this specimen, consist of 20 ribs on half a volution; the ribs begin on the umbilical wall and are there directed backwards to form a deep ventral sinus. In the hollow form of paratype UMC-IP 632, the sculpture is better preserved with sharp ribs visible as little nodes on the umbilical margin. Intercalatory ribs are irregularly distributed and begin in the midflank area. Hollow form UMC-IP 633 displays the same type of sculpture, but allows to see the ribs on the venter where they form a deep, chevron-shaped subangular sinus.

D is cussion. G. elatrous Korn et al., 2002 is a similar species but differs in the narrower umbilicus (only one fourth of the conch diameter) and the more backwardly extending ribs that become weaker during ontogeny.

\section{Nigrocyclus n. gen.}

Derivation of name. After the latin niger $=$ black, because the type species was collected in nodules within the black cherts.

Type species. Pericyclus niger Delépine, 1935.

Genus definition. Genus of the Pericylidae with lenticular conch and narrow umbilicus. Sharp ribs with convex course in juveniles and biconvex course in adults; ventral sinus chevron-shaped. Suture line with V-shaped, narrow external lobe.
Discussion. Nigrocyclus belongs to the more ancestral genera of the Pericyclidae and may be related to Goniocylus Gordon, 1986. Characteristic for the new genus, however, is the much narrower umbilicus and the constantly rectiradiate, convex or only slightly biconvex ribs. Pericyclus Mojsisovics, 1882 has also a much wider umbilicus and ribs with a convex or slightly biconvex course. The external lobe is parallel-sided in Pericyclus. Stenocyclus Schindewolf, 1951 is also lenticular, but has an oxyconic venter. The ribs form a ventral projection in Stenocyclus, in contrast to the ventral sinus in Nigrocyclus.

\section{Nigrocyclus niger (Delépine, 1935)}

Figs $8 \mathrm{~K}, \mathrm{~L}, 12$

1935 Pericyclus niger Delépine: 69, pl. 1: fig. 3.

v pt 1935a Pericyclus fasciculatus. - Böhm: 104, pl. 4: figs 3, 5 [only].

v 1935a Pericyclus niger. - Böhm: 107, pl. 4: fig. 10.

Holotype. The specimen figured by Delépine (1935: pl. 1: Fig. 3); according to Delépine it is in the collection of the Université de Poitiers.

Type locality and horizon. Cabrières (Montagne Noire); phosphoritic nodules in the Puech de la Suque Formation ('middle' Tournaisian).

Material. 6 specimens from 8 to $18 \mathrm{~mm}$ in diameter (UMC-IP 626-631). All come from St. Nazaire-de-Ladarez and were collected by Rodolphe Böhm. None of the available specimens are well preserved, and the description is based on the three individuals UMC-IP 626-628.

Diagnosis. Species of Nigrocyclus with lenticular conch (ww/dm ca. 0.45 ) and a very narrow umbilicus (uw/dm ca. 0.10 ). Adult ornament with 60 ribs, some of them intercalated in the dorsolateral area of the flanks. Rib direction in juveniles rursiradiate, in adults rectiradiate with low ventrolateral projection. Ribs wedge out near the umbilical margin.

Description. The small specimen UMC-IP 627 has, at $8 \mathrm{~mm}$ diameter, a thickly discoidal conch $(\mathrm{ww} / \mathrm{dm}=0.60)$ and an almost completely closed umbilicus (uw $/ \mathrm{dm}=0.07$. It displays 10 sharp ribs with rursiradiate direction on a quarter of a whorl; they form a wide convex arch on the flanks and a much narrower and deep chevron-shaped ventral sinus. The specimen allows examination of the suture line (Fig. 12), which in this ontogenetic stage shows a $\mathrm{V}$-shaped external lobe with strongly diverging flanks and a low median saddle.

Specimen UMC-IP 626 has, at approximately $9 \mathrm{~mm}$ diameter, a similar conch shape with an umbilicus of $1 \mathrm{~mm}$ width. It possesses 20 sharp ribs on half a whorl; these are not visible on the umbilical margin, but start in a distance of $1 \mathrm{~mm}$ from the umbilicus.

The largest available specimen UMC-IP 628 has $18 \mathrm{~mm}$ in diameter. The conch shape of this fragmentarily preserved individual was probably discoidal with a very narrow umbilicus. It displays about 


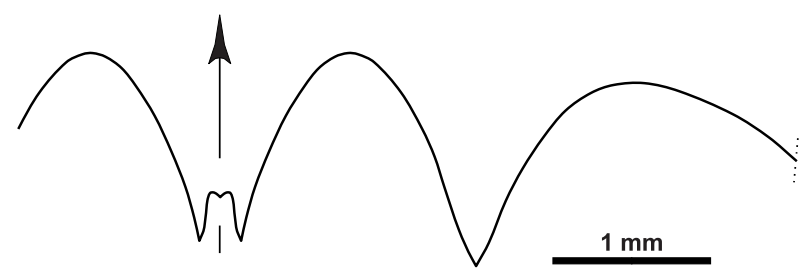

Fig. 12. Nigrocyclus niger (Delépine, 1935), suture line of specimen UMC-IP 627 (Böhm coll.) from St. Nazaire-de-Ladarez, at $4.2 \mathrm{~mm}$ ww, $3.7 \mathrm{~mm} \mathrm{wh} \times 16$.

30 coarse ribs on half a volution, and the ribs are almost as wide as their interspaces. Growth lines are visible between the ribs. In this growth stage, the course of ribs and growth lines is rectiradiate with a wide and low ventrolateral projection and a deep ventral sinus. As in the smaller specimens, the ribs wedge out in some distance from the umbilicus, remaining visible only as coarse growth lines. Intercalation of new ribs is irregular and occurs in the dorsolateral area of the flanks.

Delépine's (1935: pl. 1 Fig. 3) original figure of the type shows a specimen of $30 \mathrm{~mm}$ diameter, which closely resembles specimen UMC-IP 628 in its conch form and ornament. It has 32 ribs on half a volution; they wedge out near the umbilicus, and sometimes new ribs are intercalated.

Discussion. Juveniles of this species show affinities to some narrower umbilicate species of Goniocyclus, such as G. ammari Korn et al., 2002. In adults, however, the differences in the rib course are obvious and allow clear separation of these species.

\section{Faugères Formation}

\section{Merocanites Schindewolf, 1922}

\section{Merocanites applanatus Frech (1899)}

Figs $13 \mathrm{~A}, \mathrm{~B}, 14$

? 1883 Goniatites Henslowi. - von Koenen: 115. 1899 Prolecanites applanatus Frech: pl. 46a.

v 1935a Prolecanites (Merocanites) applanatus. - Böhm: 126, 136, pl. 7: figs $1-4,15$.

v 1935a Nomismoceras (?) sp. Böhm: 128, pl. 7: Fig. 14.

v 1982 Merocanites cf. applanatus. - Kullmann in Engel et al.: 360 .

Material. 13 specimens, representing growth stages between 9 and approximately $150 \mathrm{~mm}$ diameter. They are from Faugères (5 specimens; Böhm coll.), Cabrières (1 specimen; Böhm coll.), and Escandolgue (7 specimens; Feist and Franke coll.). Although fragmentary, the material allows interpretation of conch shape and sutural configuration. Ornament is not preserved in the material.

Description. Specimen UMC-IP 560 is a corroded, fully septate specimen of maximally $82 \mathrm{~mm}$ diameter; it has an umbilicus that is slightly wider than half of the conch diameter. Whorl width is $14 \mathrm{~mm}$ and whorl height $24 \mathrm{~mm}$.
From new material collected by Engel and Franke, a fragment of a larger specimen (MB.C.9435.1; Fig. 13B) is available for study. Height of the whorl is $42 \mathrm{~mm}$, and its width is $21.5 \mathrm{~mm}$. The flanks stand almost parallel and converge barely visible towards the continuously rounded venter. The specimen demonstrates that the imprint zone of the whorls is extremely small, and that the general conch form is almost advolute. The fragment is fully septate, and the suture line (Fig. 14) shows the characteristic outline for Merocanites: The external lobe is V-shaped with slightly concave flanks. Of the three lobes on the flank, which are all pointed and mammiform at their bases, only the outer one is asymmetric with a more sinuous ventral flank. The general form of the lobes is lanceolate. An asymmetric lobe is located on the umbilical wall, its ventral flank is oblique, and its dorsal flank almost vertical. The internal lobe is very narrow, lanceolate and so deep that subsequent suture lines touch each other.

Family Pericyclidae Hyatt, 1900

\section{Ammonellipsites Parkinson, 1822}

\section{Ammonellipsites kochi (Holzapfel, 1889)}

Fig. 13F, G

1889 Pericyclus Kochi Holzapfel: 35, pl. 3: figs 2-7.

v pt 1935a Pericyclus Kochi. - Böhm: 123, pl. 6: figs 10-12, 14, 16 [only].

1935a Pericyclus sp. Böhm: 125, pl. 6: figs 8, 9.

Ne otype. Specimen MB.C.4708.1 from Erdbach (Rhenish Mountains, Germany); proposed by Korn (2006).

Material. Seven specimens are available for study; five of them are from Faugères (Böhm coll.), one from St. Nazairede-Ladarez (Böhm coll.), and one from Péret near Cabrières. Growth stages from 15 to $105 \mathrm{~mm}$ conch diameter are represented, and most of the material is only fragmentarily preserved. The material from Faugères is tectonically distorted.

Description. Conch dimensions can best be seen in specimen UMC-IP 572 with $41 \mathrm{~mm}$ diameter, where the conch has a thinly pachyconic shape $(w w / d m=0.61)$ with an umbilicus that is a little wider than one fourth of the conch diameter. Although the umbilicus is partly obscured by matrix, it can be seen that its shoulder is broadly rounded; the umbilical wall is oblique. The specimen displays densely arranged concave ribs, standing in distances of approximately $2 \mathrm{~mm}$; they extend with a shallow and wide sinus across the venter.

The largest specimen UMC-IP 571 is, at $105 \mathrm{~mm}$ diameter, still strongly ribbed. The ribs produce an undulated pattern on the steinkern surface, and they are arranged in distances of three to four millimetres. They are as wide as their interspaces and extend with a relatively high and wide lateral projection over the flanks to form a shallow and 

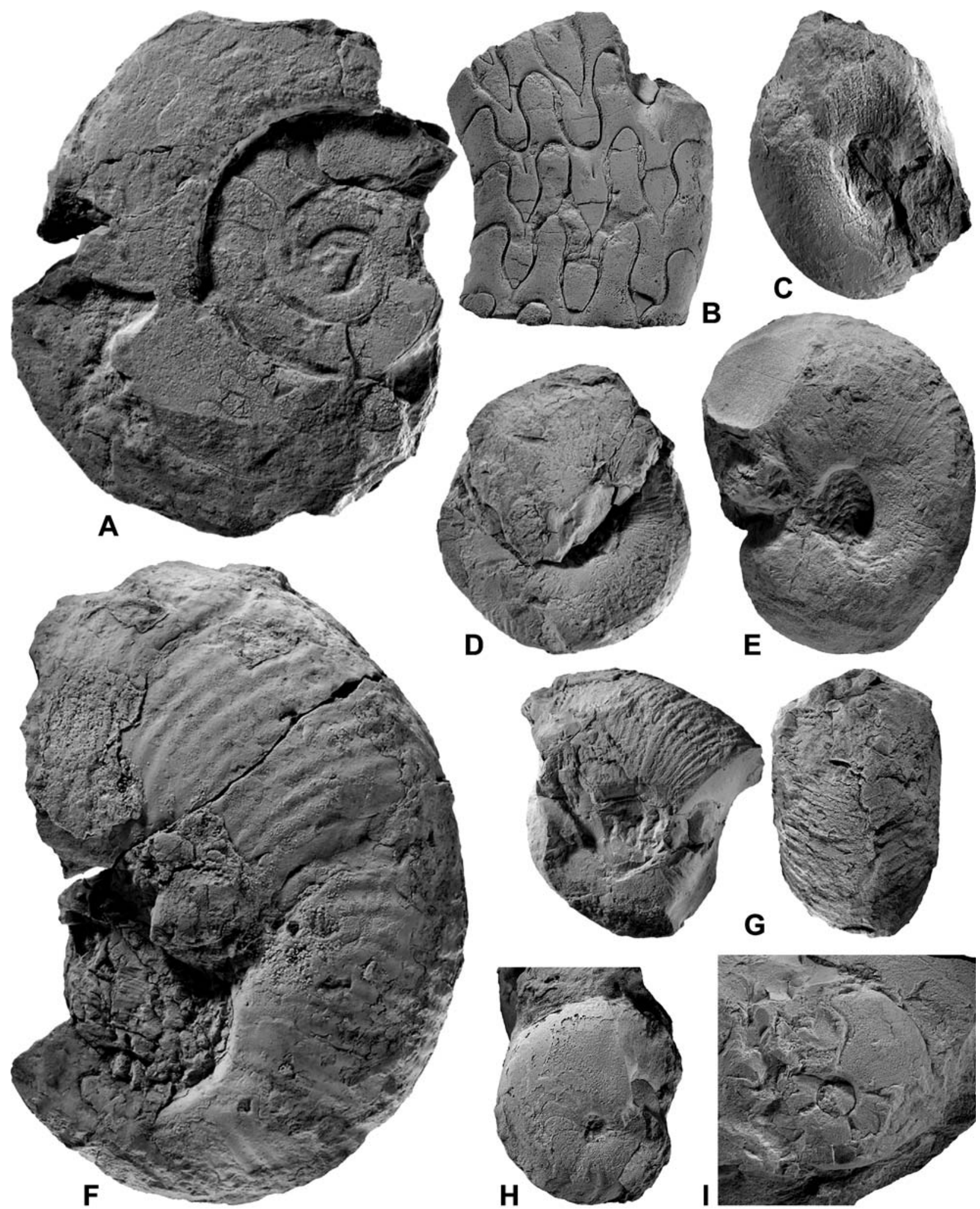

Fig. 13. Ammonoids from the Faugères Formation. A - Merocanites applanatus (Frech, 1899), specimen UMC-IP 560 (Böhm coll.) from Cabrières, lateral view; $\times 1$. B - Merocanites applanatus (Frech, 1899), specimen MB.C.9435.1 (Engel and Franke coll.) from Escandolgue, lateral view; $\times 1$. C - Ammonellipsites hauchecornei (Holzapfel, 1889), specimen UMC-IP 577 (Böhm coll.) from St. Nazaire-de-Ladarez, lateral view; $\times 2$. D - Ammonellipsites hauchecornei (Holzapfel, 1889), specimen UMC-IP 578 (Böhm coll.) from St. Nazaire-de-Ladarez, lateral view; $\times 1$. E - Ammonellipsites hauchecornei (Holzapfel, 1889), specimen MB.C.9434 (Korn 1999 coll.) from Mont Mou near Faugères, lateral view; $\times 1$. F - Ammonellipsites kochi (Holzapfel, 1889), specimen UMC-IP 571 from Péret, lateral view; $\times 1$. G - Ammonellipsites kochi (Holzapfel, 1889), specimen UMC-IP 572 (Böhm coll.) from St. Nazaire-de-Ladarez, lateral and ventral views; $\times 1$. H - Dzhaprakoceras sp., specimen UMC-IP 583 (Böhm coll.) from Faugères, lateral view; × 2. I - Winchelloceras sp., specimen UMC-IP 590 (Böhm coll.) from Faugères, lateral view; $\times 1.5$. 


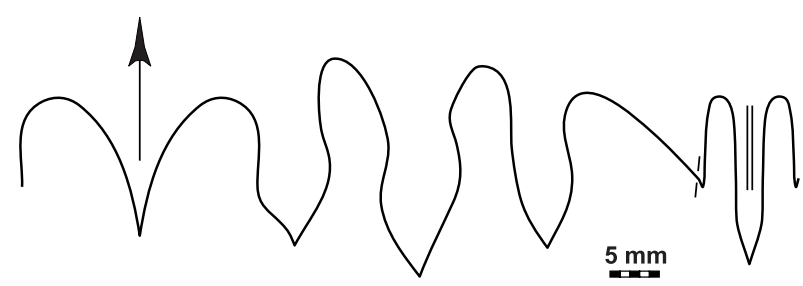

Fig. 14. Merocanites applanatus Frech (1899), suture line of specimen MB.C.9435.1 (Engel and Franke coll.) from Escandolgue, at $20.6 \mathrm{~mm}$ ww, $40.0 \mathrm{~mm} \mathrm{wh} ; \times 1$.

wide ventral sinus. Sometimes, rib splitting occurs near the umbilicus. On the preserved half volution, there are two steinkern constrictions visible, they extend parallel to the ribs. The tectonically distorted specimen does not allow a detailed description of the conch shape, but it shows a moderately wide umbilicus with subangular margin, and a broadly rounded venter.

Discussion. Almost all species of Ammonellipsites require revision. This is particularly the case for those species reported from the Erdbach Limestone of Germany; A. kochi (Holzapfel, 1889), A. hauchecornei (Holzapfel, 1889), and A. kayseri (Schmidt, 1925). Almost the entire knowledge of these three species is based on Holzapfel's (1889) monograph. The type material of these species has not been re-described and is most probably lost. Until new material is assembled and described, assignment of material from other locations must remain problematic. Of the three species of the Erdbach Limestone, A. kochi is the one that closest resembles some of the material from the Faugères Formation.

\section{Ammonellipsites hauchecornei (Holzapfel, 1889)} Figs $13 \mathrm{C}-\mathrm{E}, 15$

1889 Pericyclus Hauchecornei Holzapfel: 36, pl. 2: figs $8-11$.

v pt 1935a Pericyclus Kochi. - Böhm: 123, pl. 6: figs 7, 13, 15 [only].

v 1935a Pericyclus virgatus. - Böhm: 124, pl. 6: figs 17, 8. v pt 1935a Pericyclus Hauchecornei. - Böhm: 124.

Type material. The type material is probably lost; a neotype has thus to be designated.

Material. Nine specimens are available for study; five of them are from Faugères (Böhm coll., Korn 1999 coll) and four from St. Nazaire-de-Ladarez (Böhm coll.). Growth stages from 15 to $60 \mathrm{~mm}$ conch diameter are represented, and most of the material is only fragmentarily preserved. The material from Faugères is tectonically distorted.

Description. Specimen MB.C.9434 from Mont Mou near Faugères has almost $60 \mathrm{~mm}$ conch diameter and is, although somewhat distorted and corroded, the best preserved of the larger specimens. It is a conch with a width almost half of the diameter and an umbilicus of one fourth of the conch diameter. The umbilical margin is rounded. The
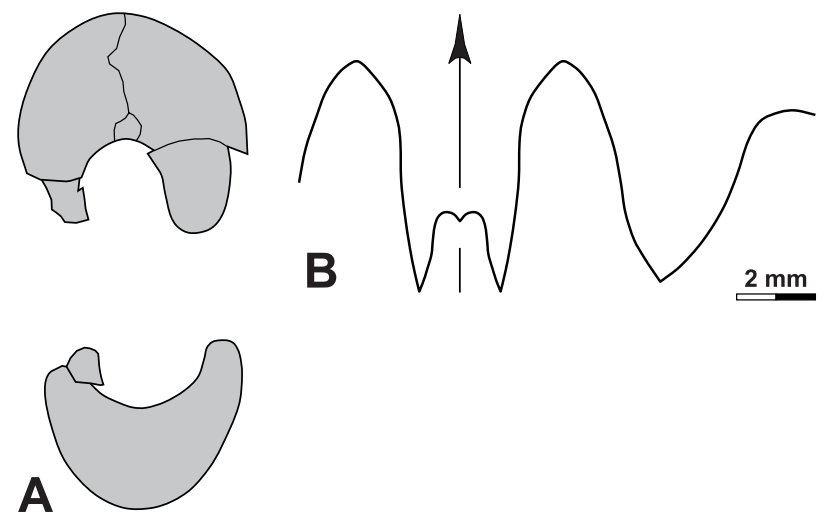

Fig. 15. Ammonellipsites hauchecornei (Holzapfel, 1889), A cross section of specimen UMC-IP 579 (Böhm coll.) from St. Nazaire-de-Ladarez; $\times 1$. B - suture line of specimen UMC-IP 577 (Böhm coll.) from St. Nazaire-de-Ladarez, at $12.4 \mathrm{~mm}$ ww, ca. $10.0 \mathrm{~mm}$ wh; $\times 4$.

ornament consists of ribs that stand two millimetres apart on the venter. They extend with a wide ventrolateral projection and a shallow ventral sinus.

The other, more fragmentary and stronger distorted specimens have a similar conch morphology and display a similar ornament. It is noteworthy that the absolute distance between the ribs is very similar in all growth stages. In specimen UMC-IP 574 , for instance, the ribs are also spaced in distances of $2 \mathrm{~mm}$, although the conch diameter is only $25 \mathrm{~mm}$.

Two specimens allow the study of the suture line. In the juvenile specimen UMC-IP 577 (Fig. 15B), at approximately $20 \mathrm{~mm}$ conch diameter, the ventral lobe is Y-shaped with parallel flanks in the lower half, it contains a low median saddle. The ventrolateral saddle is slightly asymmetric and subacute, it is narrower than the following adventive lobe. Due to erosion, this lobe is not fully exposed, but it can be seen that it is almost symmetric and V-shaped.

Discussion. Ammonellipsites hauchecornei differs from $A$. kochi in the more compressed conch (ww/ $\mathrm{dm}$ in A. hauchecornei is less than 0.50 at $50 \mathrm{~mm}$ $\mathrm{dm})$. The course of the ribs is almost straight across flanks and venter in $A$. kochi but much stronger curved in A. hauchecornei.

Family Maxigoniatitidae Korn, Klug \& Mapes, 1999

\section{Dzhaprakoceras Popov, 1965}

\section{Dzhaprakoceras sp.}

Figs 13H, 16

v 1935a Beyrichoceras cf. micronotum. - Böhm: 128, pl. 7: fig. 11.

v 1935a Glyphioceras cf. Barroisi. - Böhm: 131, pl. 7: figs 12,13 .

v pt 1935a Goniatites Haan nov. sp. Böhm: 132, pl. 7: fig. 6 [only]. 


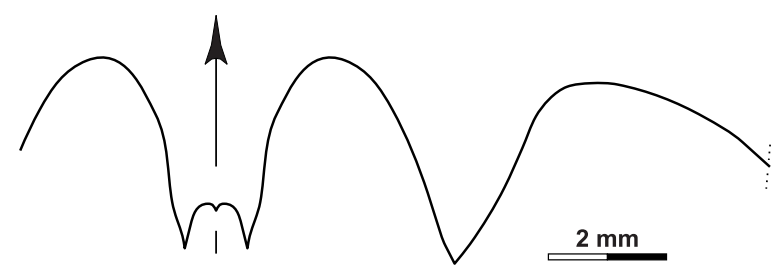

Fig. 16. Dzhaprakoceras sp., suture line of specimen UMC-IP 583 (Böhm coll.) from Faugères, at $16 \mathrm{~mm} \mathrm{dm}, 9.2 \mathrm{~mm}$ wh; $\times 6$.

Material. Three fragmentary specimens between 17 and approximately $55 \mathrm{~mm}$ conch diameter from Faugères (UMCIP 583-585; Böhm coll.). The material is too poor for exact species assignment. It is not even clear if the specimens belong to only one species.

Description. The smallest of the specimens (UMC-IP 583) shows, at $17 \mathrm{~mm}$ diameter, a very small umbilicus of little more than $1 \mathrm{~mm}$. It has four irregularly arranged steinkern constrictions, which form a ventrolateral projection. The suture line is characteristic for Dzhaprakoceras with a slightly pouched, parallel-sided external lobe, a very low median saddle, and a symmetric V-shaped adventive lobe (Fig. 16).

Larger specimens such as UMC-IP 584 and UMC-IP 585 are preserved without shell and also show steinkern constrictions with a very low ventrolateral projection and a shallow ventral sinus.

Family Girtyoceratidae Wedekind, 1918

\section{Winchelloceras Ruzhencev, 1965}

\section{Winchelloceras sp.}

\author{
Fig. 13I
} v 1935a Beyrichoceras cf. implicatum. - Böhm: 130, pl. 7 :
figs 9,10 .

Material. One specimen of approximately $23 \mathrm{~mm}$ conch diameter, embedded in nodular limestone.

Description. The only one specimen (UMC-IP 590; Böhm coll.) is a thinly discoidal conch; the umbilicus has 0.17 of the conch diameter and is bordered by a pronounced umbilical margin. The specimen is largely preserved with attached shell that shows growth lines with prominent ventrolateral projection. On the last half volution, there are three shell constrictions which parallel the course of the growth lines.

Discussion. Assignment of the specimen to a genus is difficult because of the lack of sutural characters. The conch shape and form of the constrictions speak for an attribution to Winchelloceras.

\section{Puech Capel Formation and Laurens Flysch Group}

\section{Irinoceras Ruzhencev, 1947}

\section{Irinoceras sp.}

Fig. 17D

Material. Two fragments of the shell from Puech Capel (MB.C.9430.1-2; Korn 1999 coll.). They show only the ornament with coarse growth lines that form a ventrolateral salient. Since no other genera of this time interval possess such an ornament, the specimens are assigned to Irinoceras.

Family Goniatitidae de Haan, 1825

\section{Goniatites de Haan, 1825}

\section{Goniatites sp.}

Fig. 18A

v 1935a Goniatites Haan - Böhm: 163, pl. 8: fig. 16.

v 1982 Hypergoniatites sp. - Kullmann in Engel et al.: 372.

Material. Only one specimen (UMC-IP 640), figured by Böhm (1935a), is available.

Description. The single specimen is an intensely corroded internal mould that cannot be regarded as belonging to a definite species of Goniatites. Its diameter is approximately $25 \mathrm{~mm}$, and apart from a very small umbilicus, the only visible character is the suture line. There is a V-shaped adventive lobe, a pointed ventrolateral saddle, and a narrow V-shaped external lobe with a rather low median saddle ( $1 / 3$ of the ventrolateral saddle). The external lobe has the same width as the adventive lobe. All these characteristics speak for an attribution to the genus Goniatites.

Remarks. The accompanying original label of the specimen, written by Böhm, says: "Suture de Goniatites du groupe crenistria. Viséen sup. Croix de Barrac. St.-Nazaire-de-L. Coll Böhm”. This contradicts the description in the text (p. 163), where it was stated that the specimen comes from the "Calcaire à Productus giganteus" of Vailhan, and that it was collected by Thoral. The specimen is embedded in a brown dolomitized limestone that probably contains crinoid remains. Therefore, it appears more likely that it was not collected from the flysch of the Croix de Barrac, but rather from the locality as stated in Böhm's publication.

\section{Neogoniatites Ruzhencev \& Bogoslovskaya, 1970}

\section{Neogoniatites canovasi n. sp.}

Figs 18C-F, 19

\footnotetext{
v 1982 Sudeticeras cf. mucronatum. - Kullmann in Engel et al.: 372 .

v 1982 cf. Goniatites ex gr. granosus. - Kullmann in Engel et al.: 372 .
} 

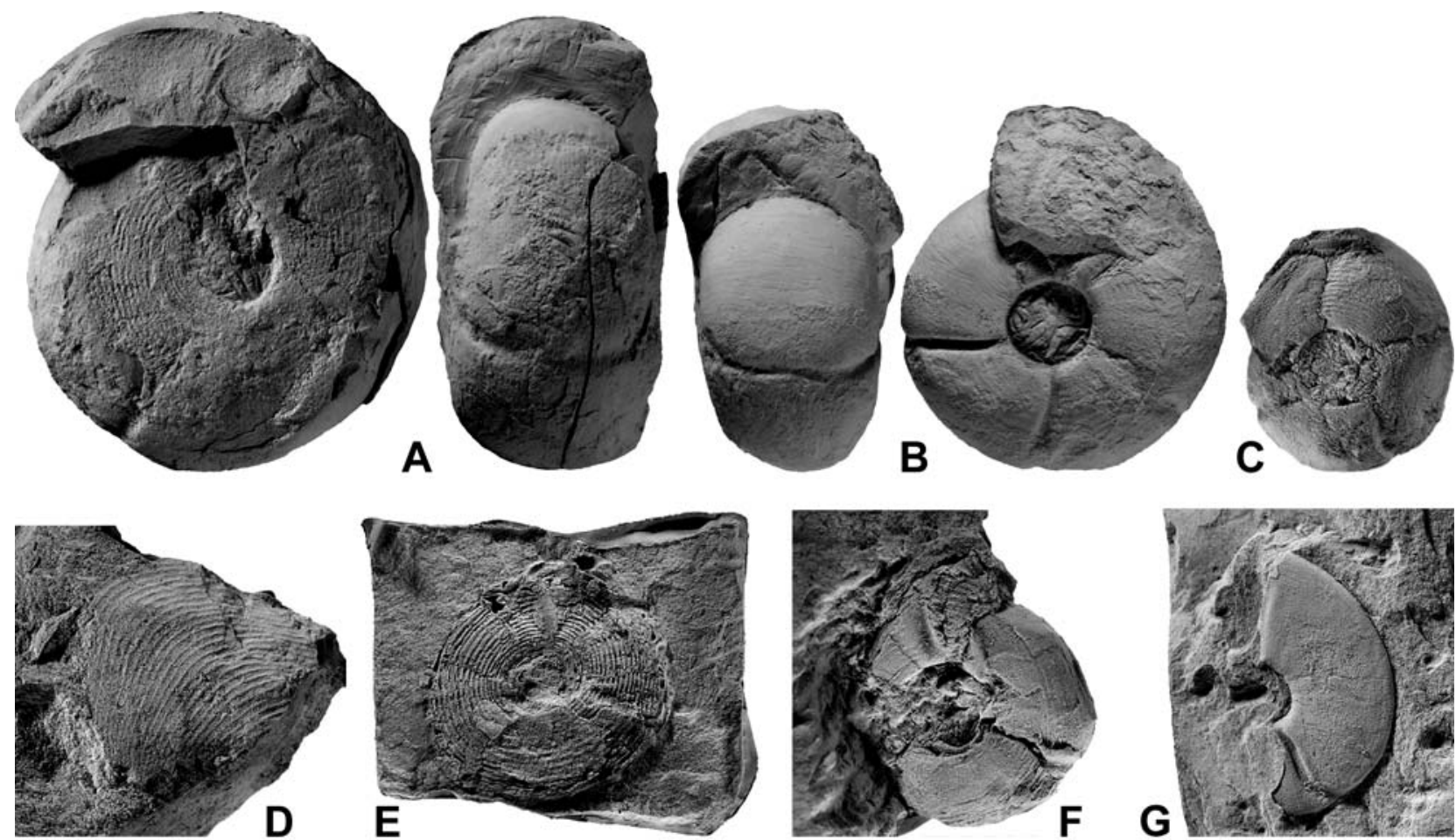

Fig. 17. Ammonoids from the Puech Capel Formation (A-D) and the 'Schistes du Landeyran' (E-G). A - Dombarites granofalcatus (Kullmann, 1961), specimen MB.C.9429.1 (Korn 1999 coll.) from Puech Capel, lateral and dorsal views; $\times 1$. B - Dombarites granofalcatus (Kullmann, 1961), specimen MB.C.9429.2 (Korn 1999 coll.) from Puech Capel, lateral and dorsal views; $\times 1$. C - Dombarites granofalcatus (Kullmann, 1961), specimen MB.C.9429.3 (Korn 1999 coll.) from Puech Capel, lateral view; $\times 1$. D - Irinoceras sp., specimen MB.C.9430.1 (Korn 1999 coll.) from Puech Capel, lateral view; $\times 1$. E - Neoglyphioceras sp., specimen UMC-IP 646 (Guiraud coll.) from the Landeyran valley (Causses-et-Veyran), lateral view; $\times 2$. F - Neoglyphioceras sp., specimen UMC-IP 647 (Guiraud coll.) from Landeyran (Causses-et-Veyran), lateral view; $\times 2.5$. G - Ferganoceras sp., specimen UMC-IP 648 (Guiraud coll.) from Landeyran (Causses-et-Veyran), lateral view; $\times 1.5$.

Derivation of name. After Florent Canovas (St. Nazaire-de-Ladarez), who collected the holotype in his vineyard.

Holotype. Specimen MB.C.9431 (Canovas coll.); illustrated here in Fig. 18C.

Type locality and horizon. Northeastern flank of Puech de la Suque, $1.5 \mathrm{~km}$ southeast of St. Nazaire-de-Ladarez (Montagne Noire); upper part of Puech Capel Formation or base of the Flysch Group (probably latest Viséan).

Material. 10 specimens, of which 9 are flattened in shales (Böhm coll., Engel and Franke coll.). Only the holotype is three-dimensionally preserved, being a slightly deformed specimen of $57 \mathrm{~mm}$ conch diameter. All the specimens display aspects of the shell ornamentation, but only the holotype allows study of the suture line. Poor preservation of some of the material prevents certain assignment to the new species.

Diagnosis. Species of the genus Neogoniatites with moderately large, thickly discoidal conch $(\mathrm{ww} / \mathrm{dm}=0.50$ at $60 \mathrm{~mm}$ $\mathrm{dm})$. Umbilicus very narrow $(\mathrm{uw} / \mathrm{dm}=0.10)$. Whorl expansion rate moderate (ca.1.75). Ornamentation with about 150 fine spiral lines and very fine, crenulated growth lines with biconvex and rectiradiate course. Adult ornament with falcate, periodically strengthened growth lines. Biconvex constrictions on the internal mould. Suture line with high median saddle (height is 0.55 of the external lobe depth), moderately wide external lobe (1.55 of the adventive lobe), and subacute ventrolateral saddle.
Description. Holotype MB.C.9431 is a specimen that, although slightly deformed by tectonics, provides sufficient information about conch morphology, shell ornament, and suture line of the new species. The conch of the specimen is thickly discoidal, with a ww/dm ratio just exceeding 0.50. Flanks and venter are broadly rounded, and also the very small umbilicus (less than one tenth of the diameter) is bordered by a regularly rounded margin.

From umbilicus to umbilicus, approximately 150 regularly spaced spiral lines can be counted, the spiral lines being narrower than their interspaces. Growth lines are only visible in the apertural portion of the specimen; they form two lateral projections of the same height, and ventrally turn back to form a ventral sinus that is twice as deep as the lateral sinus. Towards the end of the last volution, the spirals on the flanks tend to become weaker, and the growth lines show a weak indication of bundling. The internal mould possesses six constrictions that run parallel to the growth lines (Fig. 18C).

The suture line of the holotype allows assignment of the specimen to the genus Neogoniatites, in which $N$. canovasi belongs to the less advanced 

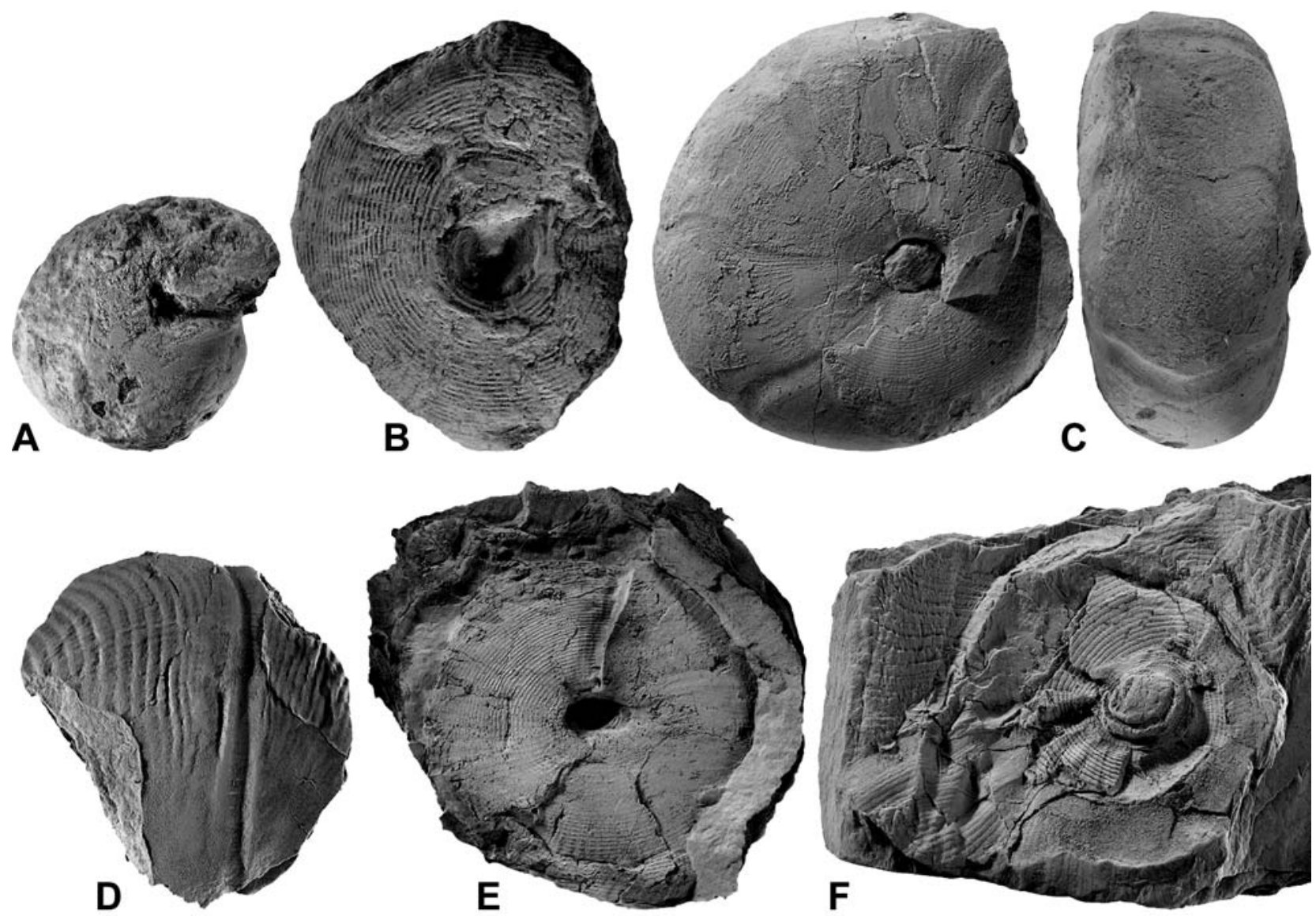

Fig. 18. Ammonoids from the Flysch Group. A - Goniatites sp., specimen UMC-IP 640 (Thoral coll.) probably from an olistholith in the flysch of Vailhan, lateral view; $\times 1.5$. B - Dombarites sp., specimen UMC-IP 641 (Böhm coll.) from St. Nazaire-de-Ladarez, lateral view; $\times 1$. C - Neogoniatites canovasi $n$. sp., holotype MB.C.9431 (Canovas coll.) from Puech de la Suque, lateral and ventral views; $\times 1$. D - cf. Neogoniatites canovasi $n$. sp., specimen UMC-IP 644 (Böhm coll.) from St. Nazaire-de-Ladarez, lateral view of an adult fragment; $\times 1$. E - Neogoniatites canovasi n. sp., paratype MB.C.9432.1 (Engel and Franke 1976 coll.) from the Barrac Valley east of St. Nazaire-de-Ladarez, lateral view of a latex cast; $\times 1$. F - Neogoniatites canovasi n. sp., paratype UMC-IP 643 (Böhm coll.) from Croix de Barrac east of St. Nazaire-de-Ladarez, lateral view; $\times 1$.

species. The V-shaped external lobe has, at its half height, 1.55 of the width of the adventive lobe, and the median saddle is a little higher than half of the $\mathrm{E}$ lobe depth. As in other species of the genus, the asymmetric ventrolateral saddle is subacute, and the adventive lobe is only slightly asymmetric (Fig. 19).

Most of the crushed specimens show also a very narrow umbilicus, and hence probably belong to the same species. The ornament is relatively well preserved in specimen UMC-IP 642; the specimen

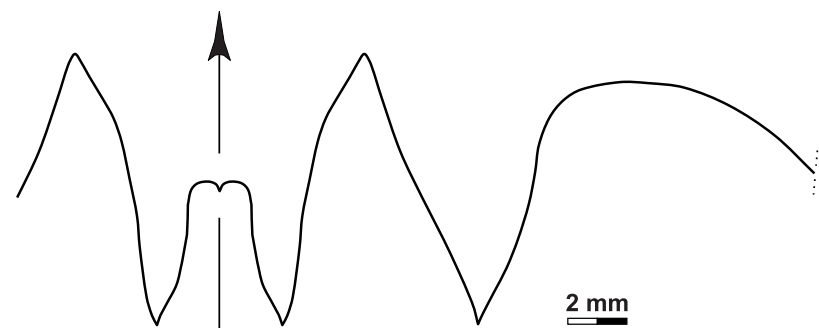

Fig. 19. Neogoniatites canovasi $\mathrm{n}$. sp., suture line of holotype MB.C.9431 (Canovas coll.) from Puech de la Suque, at ca. $23 \mathrm{~mm}$ ww, $19.5 \mathrm{~mm}$ wh; $\times 3$. is about $50 \mathrm{~mm}$ in diameter. The ornament closely resembles the holotype, both in the course of the growth lines, and in the weakening of the spirals on the flanks. Larger specimens, such as UMC-IP 643 and UMC-IP 644 show, at 40 to $50 \mathrm{~mm}$ whorl height, rhythmical strengthening of growth lines which cause faint riblets. These are well preserved on the internal mould. In such large specimens, the spiral ornament disappears on the flanks.

Discussion. Neogoniatites canovasi can be separated from most of the other species of the genus by its lower median saddle that only slightly exceeds 0.50 of the E lobe depth. In this respect, $N$. ruginosus Ruzhencev \& Bogoslovskaya, 1971 is similar, but this species lacks the spiral lines of the new species.

N. delicatus Korn, Klug \& Mapes, 1999 from the Tafilalt of Morocco has a moderately high median saddle, but in this species, the flanks of external and adventive lobes are much more sinuous. N. worki Korn \& Ebbighausen, 2006, also from the Tafilalt of Morocco, has a similar conch geometry but is fully covered with spiral lines. 
Stratigraphic and geographic distribution. Species of Neogoniatites are known to occur near the Viséan-Namurian boundary. Best known are the occurrences of $N$. ruginosus Ruzhencev \& Bogoslovskaya, 1971 and N. milleri Ruzhencev \& Bogoslovskaya, 1970, which occur in the Nm1a1 to Nm1b1 "zones" of the South Urals, i.e., time equivalents of the latest Viséan and earliest Namurian of Central and Northern Europe.

Family Agathiceratidae von Arthaber, 1911

\section{Dombarites Librovitch, 1957}

Dombarites granofalcatus (Kullmann, 1961)

Figs $17 \mathrm{~A}-\mathrm{C}, 20$

1961 Goniatites (Goniatites) granofalcatus Kullmann: 305, pl. 22: figs $1,2$.

2006 Dombarites granofalcatus. - Korn \& Ebbighausen in Klug et al.: 37, figs 31C, D, 34, 35 (for more synonymy).

Material. Seven fragmentary specimens (Korn 1999 coll.) between 12 and $50 \mathrm{~mm}$ conch diameter. They come from a marly limestone of the Puech Capel Formation and are not well preserved. Ornament details as well as suture lines are visible and allow specific assignment of the specimens. Additionally, one questionable specimen (UMC-IP 641; Böhm coll.) from St. Nazaire-de-Ladarez.

Description. The largest of the specimens (MB.C.9429.1) is a somewhat distorted conch with a thickly discoidal shape $(\mathrm{ww} / \mathrm{dm}=0.54)$ and a narrow umbilicus (uw/dm $=0.20$ ). It has almost parallel flanks and a narrowly rounded umbilical wall; the venter is broadly rounded. Remains of the shell are preserved, they show an ornament that is dominated by spiral lines. The steinkern bears internal constrictions.

Specimen MB.C.9429.2 is a steinkern with diameter of $42 \mathrm{~mm}$ and shows a conch shape, which is a little bit thicker $(\mathrm{ww} / \mathrm{dm}=0.62)$ and wider umbilicate $(\mathrm{uw} / \mathrm{dm}=0.26)$. It has five constrictions on the last whorl; these extend with rursiradiate direction almost linearly across flanks and venter.

The suture line of specimen MB.C.9429.3 (Fig. 20) has a Y-shaped external lobe with subparallel flanks in the lower two thirds and a median saddle that has a height of about 0.40 of the external lobe depth. The tectiform ventrolateral saddle is as wide

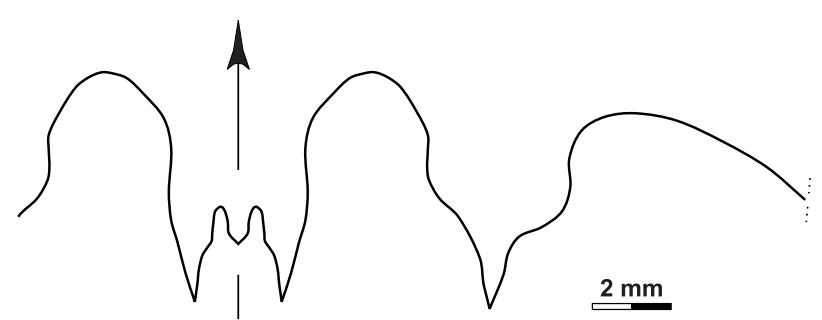

Fig. 20. Dombarites granofalcatus (Kullmann, 1961), suture line of specimen MB.C.9429.3 (Korn 1999 coll.) from Puech Capel, at ca. $24 \mathrm{~mm}$ ww, ca $11 \mathrm{~mm}$ wh; $\times 4$. as the external lobe, and the asymmetric adventive lobe is rather strongly pouched. Although obtained from a specimen of approximately $30 \mathrm{~mm}$ conch diameter, it shows some juvenile aspects, such as the rounded ventrolateral saddle.

Stratigraphic and geographic distribution. The stratigraphic distribution is not completely clear. According to the co-occurrence with Neogoniatites etc. in North Africa, it probably falls within the latest Viséan (Korn \& Ebbighausen in Klug et al. 2006). The species is known from several places in the Cantabrian Mountains of Spain and from the Tafilalt of Morocco.

Family Neoglyphioceratidae Plummer \& Scott, 1937

\section{Neoglyphioceras Brüning, 1923}

\section{Neoglyphioceras sp.} Fig. 17E, F

v 1935a Goniatites subcircularis. - Böhm: 148, pl. 8: fig. 1.

v 1982 Neoglyphioceras cf. caneyanum. - Kullmann in Engel et al.: 372 .

v 1982 Pachylyroceras cf. angustum. - Kullmann in Engel et al.: 372 .

Material. Two small (15 $\mathrm{mm}$ in diameter), crushed specimens (UMC-IP 646, UMC-IP 647; Guiraud coll.) from Landeyran are available for study. Both are insufficiently preserved to allow exact species designation.

Description. Both specimens have an umbilicus that is about one fourth of the shell diameter. Approximately 20 sharp spiral lines with equal distances can be counted from the umbilicus to the midventer. Specimen UMC-IP 646 displays very fine growth lines between the spirals, they extend with a shallow concave arc over the inner flanks and project to a low ventrolateral projection. Specimen UMC-IP 647 possesses three constrictions, which are especially well preserved on the steinkern. Their course is concave-convex with a ventrolateral projection and a shallow ventral sinus. Using this character, they can be assigned to Neoglyphioceras.

Family Ferganoceratidae Ruzhencev, 1960

Ferganoceras Librovitch, 1957

Ferganoceras sp.

Fig. $17 \mathrm{G}$

v 1935a Sagittoceras sp. - Böhm: 149 pl. 8: fig. 2.

Material. One small (15 $\mathrm{mm}$ in diameter) and poorly preserved, crushed specimen (UMC-IP 648; Guiraud coll.) from Landeyran is available for study.

Description. The specimen is a fragment of a steinkern and shows only the strongly curved con- 
striction and traces of a rather coarse spiral ornament. It can thus not be attributed to a distinct species.

\section{Acknowledgements}

D. K. thanks the Centre National de la Recherche Scientifique (CNRS) for the support to stay in Montpellier in 1999. We are indebted to Wolfgang Gerber (Tübingen) for the production of the photographic illustrations. We acknowledge the reviews of the manuscript by Wolfgang Franke (Frankfurt), Christian Klug (Zürich), and John Tilsley (Sheffield). This is a contribution to UMR 5554 (ISEM 2006084).

\section{References}

Arthaber, G. von 1911. Die Trias von Albanien. - Beiträge zur Paläontologie und Geologie Österreichs und Ungarns 24: $169-177$.

Becker, R. T. \& Weyer, D. 2004. Bartzschiceras n. gen. (Ammonoidea) from the Lower Tournaisian of Southern France. Mitteilungen aus dem Geologisch-Paläontologischen Institut der Universität Hamburg 88: 11-36.

Bergeron, J. 1899a. Note sur la base du Carbonifère dans la Montagne Noire. - Bulletin de la Société géologique de France, 3ème série 27: 36-43.

- 1899b. Études des terrains paléozoïques et de la tectonique de la Montagne Noire. - Bulletin de la Société géologique de France, 3ème série 27: 617-678.

Bessière, G., Mirouse, R. \& Perret, M.-F. 1980. Decouverte de faunes de la limite Viséen-Namurien sous le "Culm" carbonifère du Massif de Mouthoumet (Aude). - Comptes Rendus Hebdomadaires des seances de l'Académie des Sciences Paris, série D 291: 521-524.

Blayac, J., Böhm, R. \& Delépine, G. 1935a. Sur l'âge de l'horizon à lydiennes de la base du Carbonifère de la Montagne Noire. - Comptes rendus de l'Académie des Sciences de Paris 200: 476-478.

- 1935b. Une nouvelle faune de Goniatites dans le Viséen de la Montagne Noire. - Comptes rendus de l'Académie des Sciences de Paris 200: 1612-1613.

Bockwinkel, J. \& Ebbighausen, V. 2006. A new ammonoid fauna from the Gattendorfia-Eocanites Genozone of the Anti-Atlas (Early Carboniferous; Morocco). - Fossil Record 9 (1): 87-129.

Böhm, R. 1935a. Études sur les faunes du Dévonien Supérieur et du Carbonifère Inférieur de la Montagne Noire. 203 pp.; Montpellier (Charité).

- 1935b. Études sur la flore de l'horizon à lydiennes de la base du Carbonifère de la Montagne Noire. - 31 pp., Montpellier (Charité).

- 1936. Le Carbonifère de la Montagne Noire, ses faunes de goniatites, ses subdivisions, ses rapports avec le Dévonien. $-69^{\mathrm{e}}$, Congrès des Sociétés Savantes, Montpellier: 93-98.

Boyer, F., Krylatov, S., Le Fèvre, J. \& Stoppel, D. 1968. Le Dévonien supérieur et la limite Dévono-Carbonifère en Montagne Noire (France). - Bulletin du Centre des recherches de Pau-SNPA 2 (1): 5-33.

Brauckmann, C., Chlupáć, I. \& Feist, R. 1993. Trilobites at the Devonian-Carboniferous boundary. - Annales de la Société Géologique de Belgique 115 (2) (for 1992): 507518.

Brüning, K. 1923. Beiträge zur Kenntnis des Rheinisch-westfälischen Unterkarbons, insbesondere der Goniatiten und Korallen in der stratigraphischen Stellung und Gliederung. 59 pp.; Marburg.
Colmenero, J. R., Fernández, L. P., Moreno, C., Bahamonde, J. R., Barba, P., Heredia, N. \& González, F. 2002. Carboniferous. - In Gibbons, W. \& Moreno, T. (eds). The Geology of Spain: 93-116, Geological Society of London:

Coudray J., Feist, R., Galtier, J. \& Michel, D. 1979. Nouvelles precisions sur l'âge et le paléoenvironnement des lydiennes à nodules phosphatés du Mont Peyroux (Montagne Noire) et de leur encaissant carbonaté. Comptes rendus de la $7^{\mathrm{e}}$ réunion annuelle des Sciences de la Terre, Lyon 1979. Société géologique de France (édit.): 132.

Deflandre, G. 1946. Radiolaires et Hystrichosphaeridae du Carbonifère de la Montagne Noire. - Comptes rendus de l'Académie des Sciences 223: 515-517.

- 1973. Sur quelques nouvelles espèces d'Archocyrtium, Radiolaires Pylentonemidae du Viséen de Cabrières. Comptes rendus de l'Académie des Sciences 277: 149_ 152.

Delépine, G. 1935. Contribution a l'étude de la faune du Dinantien des Pyrénées. Première partie. Goniatites et crustacés des nodules phosphatés de l'Ariège. - Bulletin de la Société géologique de France, 5ème série 5: 65-75.

- 1937. Le Carbonifère du Sud de la France (Pyrénées et Montagne Noire) et du Nord-Ouest de l'Espagne (Asturies). - Comptes rendus du 2ème Congrès pour l'avancement des études de Stratigraphie Carbonifère - Heerlen 1935: 139-158.

Engel, W., Feist, R. \& Franke, W. 1978. Synorogenic gravitational transport in the Carboniferous of the Montagne Noire (S-France). - Zeitschrift der Deutschen Geologischen Gesellschaft 129: 461-472.

- 1982. Le Carbonifère anté-stéphanien de la Montagne Noire: rapports entre mise en place des nappes et sédimentation. - Bulletin du B.R.G.M, 2ème serie, Section I, 4 (for 1980-1981): 341-389.

Feist, R. 1985. Devonian Stratigraphy of the Southeastern Montagne Noire (France). - Courier Forschungsinstitut Senckenberg 75: 331-352.

Feist, R., Flajs, G. \& Girard, C. 2000. The strato-type section of the Devonian-Carboniferous boundary. - Courier Forschungsinstitut Senckenberg 226: 77-82, Frankfurt.

Feist, R. \& Galtier, J. 1985. Découverte de flores d'âge namurien probable dans le flysch à olistolites de Cabrières (Herault). Implication sur la durée de la sédimentation synorogénetique dans la Montagne Noire (France méridionale). - Comptes rendus de l'Académie des Sciences de Paris 300, Série II, $n^{\circ}$ 6: 207-212.

Flajs, G. \& Feist, R. 1988. Index conodonts, trilobites and environment of the Devonian-Carboniferous Boundary beds at La Serre (Montagne Noire, France). - Courier Forschungsinstitut Senckenberg 100: 53-107.

Foord, A. H. 1901. Monograph of the Carboniferous Cephalopoda of Ireland, Part IV, Containing the families Solenocheilidae (concluded) and Glyphioceratidae. - Palaeontological Society 55: $127-146$.

- 1903. Monograph of the Carboniferous Cephalopoda of Ireland, Part V, Containing the families Glyphioceratidae (concluded) and Prolecanitidae, with title-page and index. - Palaeontological Society 57: 147-234.

Frech, F. 1897-1902. Lethaea geognostica oder Beschreibung und Abbildung der für die Gebirgs-Formationen bezeichnendsten Versteinerungen. I. Theil. Lethaea palaeozoica. 2. Band. IV: 257-452; Stuttgart (Schweizerbart). pp. 1-283: 1897, pp. 284-471: 1899, pp. 472 ff.: 1902.

Furnish, W. M. \& Manger, W. L. 1973. Type Kinderhook Ammonoids. - Proceedings of the Iowa Acadademy of Science 80: $15-24$.

Galtier, J., Meyer-Berthaud, B. \& Rowe, N. J. 1988. Tournaisian plants from the "Lydiennes" Formation of the Montagne Noire (France). - Courier Forschungsinstitut Senckenberg 100: 109-117.

Genson, E. 1940. Découverte d'une flore dans l'horizon à lydiennes de la base du carbonifère du Massif du Foulon. Eugène Genson, Béziers, 6: 1-6. 
- 1941. Nouvelles découvertes dans l'horizon à lydiennes de la base du Carbonifère de la région de Concous. Eugène Genson, Béziers, 8: 1-6.

Girard, C. 1994. Conodont Biofacies and Event stratigraphy across the $\mathrm{D} / \mathrm{C}$ Boundary in the stratotype area (Montagne Noire, France). - Courier Forschungsinstitut Senckenberg 168, Willi Ziegler-Festschrift I: 299-309.

Gordon, M. jr. 1986. Late Kinderhookian (Early Mississippian) Ammonoids of the Western United States. - Journal of Paleontology, Memoir 19: 1-36.

Haan, G. de 1825. Monographia Ammoniteorum et Goniatiteorum. 168 pp., Lugduni Batavorum (Hazenberg).

Holzapfel, E. 1889. Die Cephalopoden-führenden Kalke des unteren Carbon von Erdbach-Breitscheid bei Herborn. Palaeontologische Abhandlungen, Neue Folge 1 (1): 1-74.

Hyatt, A. 1883-1884. Genera of fossil cephalopods. - Proceedings of the Boston Society of Natural History 22: 253-338 (253-272 publ. 1883, 273-338 publ. 1884).

- 1900. Tetrabranchiate Cephalopoda. - In Zittel-Eastman: Text-book of palaeontology.1, 1st edition: 502-604; London.

Kaiser, S. I. 2005. Mass extinctions, climatic and oceanographic changes at the Devonian/Carboniferous boundary. Unpublished Dissertation, University of Bochum, $156 \mathrm{pp}$.

Klug, C., Döring, S., Korn, D. \& Ebbighausen, V. 2006. The Viséan sedimentary succession at the Gara el Itima (AntiAtlas, Morocco) and its ammonoid faunas. - Fossil Record 9 (1): 3-60.

Koenen, A. von 1883. Sur le Dévonien supérieur et le Carbonifère de l'Hérault. - Bulletin de la Société géologique de France, 3ème série 12: 114-115.

Korn, D. 1993. The ammonoid faunal change near the Devonian-Carboniferous boundary. - Annales de la Société Géologique de Belgique 115 (for 1992): 581-593.

- 1994. Oberdevonische und unterkarbonische Prionoceraten aus dem Rheinischen Schiefergebirge. - Geologie und Paläontologie in Westfalen 30: 1-85

- 1996. Revision of the Late Viséan goniatite stratigraphy. Annales de la Société Géologique de Belgique 117 (2): 205-212.

- 1997a. The Palaeozoic ammonoids of the South Portuguese Zone. - Memórias do Instituto Geológico e Mineiro de Portugal 33: 1-132.

- 1997b. Evolution of the Goniatitaceae and Viséan-Namurian biogeography. - Acta Palaeontologica Polonica 42 (2): 177-199.

- 2005. Carboniferous ammonoid stratigraphy based on poorly preserved material - a discussion of Becker \& Weyer (2004). - Mitteilungen aus dem Geologisch-Paläontologischen Institut der Universität Hamburg 89: 4954.

- 2006. Ammonoideen. - Schriftenreihe der Deutschen Gesellschaft für Geowissenschaften 41: 147-170.

Korn, D., Bockwinkel, J. \& Ebbighausen, V. 2007. The Tournaisian and Viséan ammonoid stratigraphy in North Africa. - Neues Jahrbuch für Geologie und Paläontologie, 243: 127-148.

Korn, D., Klug, C., Ebbighausen, V. \& Bockwinkel, J. 2002. Palaeogeographical meaning of a Middle Tournaisian ammonoid fauna from Morocco. - Geologica et Palaeontologica 36: 79-86.

Korn, D., Klug, C. \& Mapes, R. 1999. Viséan and Early Namurian Ammonoids from the Tafilalt (Eastern AntiAtlas, Morocco). - In Feist, R., Talent, J. A. \& Daurer, A. (eds). Abhandlungen der Geologischen Bundesanstalt, 54, North Gondwana: Mid-Paleozoic Terranes, Stratigraphy and Biota: $345-375$.

Krylatov, S. 1964. Sur les relations des lydiennes dinantiennes à nodules phosphatés de Saint-Nazaire de Ladarez (Hérault) avec leur substratum calcaire, et le problème de la lacune du Tournaisian. - Bulletin de la Société géologique de France, Comptes rendus sommaire 7 (6): 258260.
Kullmann, J. 1961. Die Goniatiten des Unterkarbons im Kantabrischen Gebirge (Nordspanien). I. Stratigraphie. Paläontologie der U.O. Goniatitina Hyatt. - Neues Jahrbuch für Geologie und Paläontologie, Abhandlungen 113 (3): 219-326.

Kusina, L. F. 1980. Saurskie ammonoidei. - Trudy Paleontologicheskogo Instituta Akademiya Nauk SSSR 181: 1-108.

Lethiers, F. \& Feist, R. 1985. Ostracodes, stratigraphie et bathymétrie du passage Dévonien-Carbonifère au Viséen Inférieur en Montagne Noire (France). - Geobios 24 (1): 71-104.

Librovitch, L. S. 1927. Nizhnekamennougol'nye golovonogie iz rayona ozera Son-kul' (Tyan' Shan'). - Mater. obshch. prikl. geol., Geol. kom., vyp. 74: 1-55.

- 1957. O nekotorykh novykh gruppakh goniatitov iz kamennougol'nykh otlozheniy SSSR. - Ezhegodnik Vsesoyuznogo Paleontologicheskogo Obsshchestva 16: 246272.

Maurel, M. 1966. Position stratigraphique des flores du Viséen de la Montagne Noire. - Annales de la Société d'Horticulture et d'Histoire Naturelle de l'Hérault 4: 277-289.

Meyer-Berthaud, B. 1984a. Les axes de Lycophytes à structure anatomique conservée du Carbonifère basal/Tournaisien) de la Montagne Noire: Trabicaulis gen. nov. et Landeyrodendron gen. nov. - Palaeontographica B 190: $1-36$.

- 1984b. Stenomyelon from the upper Tournaisian of the Montagne Noire (France). Canadian Journal of Botany 62 (11): 2297-2307.

Michel, D. 1981. Paléoenvironnement des calcaires noduleux et lydiennes en Montagne Noire (Dévonien sup.-Dinantien): Sédimentologie, approche expérimentale et géochimie. - Thèse, Université de Paris-Sud (Centre d'Orsay): 385 pp. (unpublished).

Miller, A. K. \& Collinson, C. 1951. Lower Mississippian ammonoids of Missouri. - Journal of Paleontology 25: 454-487.

Miller, A. K. \& Furnish, W. M. 1954. The classification of the Paleozoic ammonoids. - Journal of Paleontology 28: 685-692

Miller, S. A. \& Gurley, W. F. E. 1896. New species of Palaeozoic invertebrates from Illinois and other states. - Bulletin of the Illinois State Museum of Natural History 11: $1-50$.

Münster, G. Graf zu 1832. Ueber die Planuliten und Goniatiten im Uebergangs-Kalk des Fichtelgebirges. - 38 pp.; Bayreuth (Birner)

- 1839. Nachtrag zu den Goniatiten des Fichtelgebirges. Beiträge zur Petrefactenkunde 1: 43-55.

Paproth, E., Feist, R. \& Flajs, G. 1991. Decision on the Devonian-Carboniferous Boundary Stratotype. - Episodes 14 (4): 331-336.

Parkinson, J. 1822. Introduction to the study of fossil organic remains. 346 pp., London.

Phillips, J. 1841. Figures and descriptions of the Palaeozoic fossils of Cornwall, Devon, and West Somerset. 231 pp., London.

Plummer, F. B. \& Scott, G. 1937. Upper Paleozoic Ammonites in Texas. - The Geology of Texas, Vol. III, Pt. 1, University of Texas Bulletin 3701: 1-516.

Popov, A. V. 1965. Novye vizeyskie ammonoidei Tyan'-Shanya. - Paleontologicheskiy Zhurnal 1965 (2): 35-49.

- 1968. Vizeyskie ammonoidei cevernogo Tyan'-Shanya i ikh stratigraficheskoe zhachenie. - Tyan'Shanya Akademiya Nauk Kirgizkoy SSR, Inst. Geologii: 1-116; Frunze.

Pruvost, P. 1914. Observations sur les terrains Dévoniens et Carbonifères du Portugal et leur faune. - Comunicações da Commissão do Serviço Geológico de Portugal 10 (1): $1-21$.

Robardet, M., Verniers, J., Feist, R. \& Paris, F. 1994. Le Paléozoïque anté-varisque de France, contexte paléogéographique et géodynamique. - Géologie de la France 3: 3-31. 
Rolfe, W. D. I. 1985. Form and function in Thylacocephala, Conchyliocarida and Concavicarida (?Crustacea): a problem of interpretation. - Transactions of the Royal Society of Edinburgh 76: 391-399.

Rowe, N. P. \& Galtier, J. 1989. A Lower Carboniferous plant assemblage from La Serre (Montagne Noire, France). 1. Review of Palaeobotany and Palynology 61: 239-271.

- 1990. A Lower Carboniferous plant assemblage from La Serre (Montagne Noire, France). 2. Gymnosperms. Review of Palaeobotany and Palynology 63: 91-115.

Ruan Yiping 1981. Devonian and earliest Carboniferous Ammonoids from Guangxi and Guizhou. - Memoires of Nanjing Institute of Geology and Paleontology, Academia Sinica 15: $1-152$.

Ruzhencev, V. E. 1947. Novyy rod iz semeystva Cheiloceratidae v namyurskikh otlozheniyakh Urala. - Doklady Akademii Nauk SSSR 57 (3): 281-284.

- 1960. Printsipy sistematiki, sistema i filogeniya paleozoyskikh ammonoidey. - Trudy Paleontologicheskogo Instituta Akademiya Nauk SSSR 133: 1-331.

- 1965. Osnovnye kompleksy ammonoidei kamennougol'nogo perioda. - Paleontologicheskiy Zhurnal 1965 (2): 3-17.

Ruzhencev, V. E. \& Bogoslovskaya, M. F. 1970. Reviziya nadsemeystva Goniatitaceae. - Paleontologicheskiy Zhurnal 1970 (4): 52-65.

- 1971. Namyurskiy etap v evolyutsii ammonoidey. Rannenamyurskie ammonoidei. - Trudy Paleontologicheskogo Instituta Akademiya Nauk SSSR 133: $1-382$.

Schindewolf, O. H. 1920. Neue Beiträge zur Kenntnis der Stratigraphie und Paläontologie des deutschen Oberdevons. - Senckenbergiana 2: 114-129.

- 1922). Über eine Unterkarbonfauna aus Ostthüringen. Senckenbergiana 4: 8-20.

- 1923. Beiträge zur Kenntnis des Paläozoikums in Oberfranken, Ostthüringen und dem Sächsischen Vogtlande. I. Stratigraphie und Ammoneenfauna des Oberdevons von Hof a. S. - Neues Jahrbuch für Mineralogie, Geologie und Paläontologie, Beilage-Band 49: 250-357, 393509.

- 1926a. Beiträge zur Kenntnis der Cephalopodenfauna des oberfränkisch-ostthüringischen Unterkarbons. - Senckenbergiana 8: $63-96$.
- 1926b. Zur Kenntnis der Devon-Karbon-Grenze in Deutschland. - Zeitschrift der Deutschen Geologischen Gesellschaft 78: 88-133.

- 1939. Bemerkungen zur Stratigraphie des oberfränkischostthüringischen Unterkarbons. - Jahrbuch der Preußischen Geologischen Landesanstalt 59 (for 1938): 456-475.

- 1951. Über ein neues Vorkommen unterkarbonischer Pericyclus-Schichten im Oberharz. - Neues Jahrbuch für Geologie und Paläontologie, Abhandlungen 93 (1): $23-$ 116.

Schmidt, H. 1925. Die carbonischen Goniatiten Deutschlands. - Jahrbuch der Preußischen Geologischen Landesanstalt 45 (for 1924): 489-609.

Sowerby, J. 1812-1814. The mineral conchology of Great Britain; or coloured figures and descriptions of those remains of testaceous animals or shells, which have been preserved at various times and depths in the earth. Vol. I, 234 pp., London.

Théron, H. l'abbé 1899. Note sur les gisements de phosphate de chaux du Pic de Cabrières. Faune et Flore des Lydiennes noires. - Bulletin de la Société d'Étude des Sciences naturelles de Béziers 22: 105-112.

Vachard, D. 1977. Étude stratigraphique et micropaléontologique (algues et foraminifères) du Viséen de la Montagne Noire. - Mémoires de l'Institut géologique de l'Université de Louvain 29: 111-195.

Vöhringer, E. 1960. Die Goniatiten der unterkarbonischen Gattendorfia-Stufe im Hönnetal (Sauerland). - Fortschritte in der Geologie von Rheinland und Westfalen 3,1: 107196.

Wedekind, R. 1918. Die Genera der Palaeoammonoidea (Goniatiten). Mit Ausschluß der Mimoceratidae, Glyphioceratidae und Prolecanitidae. - Paläontographica 62: 85-184.

Weyer, D. 1972. Trilobiten und Ammonoideen aus der Entogonites nasutus-Zone (Unterkarbon) des Büchenberg-Sattels (Elbingeröder Komplex, Harz). Teil I. - Geologie 21 (2): 166-184.

Winchell, A. 1862. Notice of the rocks lying between the Carboniferous limestone of the lower Peninsula of Michigan and the limestones of the Hamilton group: with descriptions of some cephalopods supposed to be new to science. American Journal of Science and Arts, $2^{\text {nd }}$ series 33 (2): $352-366$. 


\section{Appendix}

Conch dimensions and ratios of ammonoids from the Montagne Noire. HT = holotype; PT = paratype

\begin{tabular}{|c|c|c|c|c|c|c|c|c|c|c|}
\hline & $\mathrm{dm}$ & ww & wh & uw & ah & $\mathrm{ww} / \mathrm{dm}$ & ww/wh & $\mathrm{uw} / \mathrm{dm}$ & WER & IZR \\
\hline \multicolumn{11}{|c|}{ Acutimitoceras subbilobatum (Münster, 1839) } \\
\hline MB.C.9420.1 & 20.4 & 9.4 & 12.9 & 0.0 & 5.8 & 0.46 & 0.73 & 0.00 & 1.96 & 0.55 \\
\hline \multicolumn{11}{|c|}{ Acutimitoceras intermedium (Schindewolf, 1923) } \\
\hline MB.C. 9428 & 41.6 & 22.2 & 23.7 & 1.5 & 11.4 & 0.53 & 0.94 & 0.04 & 1.90 & 0.52 \\
\hline \multicolumn{11}{|l|}{ Nicimitoceras sp. 1} \\
\hline \multirow[t]{12}{*}{ MB.C. 9425.2} & 43.9 & 19.2 & 24.3 & 1.45 & 11.6 & 0.44 & 0.79 & 0.03 & 1.85 & 0.52 \\
\hline & 32.3 & 14.3 & 18.1 & 1.15 & 9.3 & 0.44 & 0.79 & 0.04 & 1.97 & 0.49 \\
\hline & 23.0 & 10.8 & 13.4 & 0.75 & 6.6 & 0.47 & 0.81 & 0.03 & 1.96 & 0.51 \\
\hline & 16.4 & 8.5 & 9.4 & 0.52 & 4.6 & 0.52 & 0.90 & 0.03 & 2.00 & 0.51 \\
\hline & 11.6 & 6.6 & 6.7 & 0.66 & 3.5 & 0.57 & 0.99 & 0.06 & 2.05 & 0.48 \\
\hline & 8.1 & 5.2 & 4.35 & 0.78 & 2.15 & 0.64 & 1.20 & 0.10 & 1.85 & 0.51 \\
\hline & 5.95 & 3.85 & 3.02 & 0.73 & 1.57 & 0.65 & 1.28 & 0.12 & 1.85 & 0.48 \\
\hline & 4.38 & 3.24 & 2.22 & 0.78 & 1.09 & 0.74 & 1.46 & 0.18 & 1.81 & 0.51 \\
\hline & 3.29 & 2.29 & 1.40 & 0.74 & 0.80 & 0.69 & 1.64 & 0.22 & 1.74 & 0.43 \\
\hline & 2.49 & 1.77 & 1.11 & 0.66 & 0.65 & 0.71 & 1.59 & 0.27 & 1.83 & 0.41 \\
\hline & 1.84 & 1.29 & 0.77 & 0.58 & 0.52 & 0.69 & 1.67 & 0.32 & 1.94 & 0.32 \\
\hline & 1.32 & 0.94 & 0.58 & 0.37 & 0.43 & 0.71 & 1.62 & 0.33 & 1.93 & 0.26 \\
\hline \multirow[t]{10}{*}{ MB.C.9425.2 } & 35.5 & 17.2 & 20.4 & 0.50 & 10.0 & 0.48 & 0.84 & 0.01 & 1.94 & 0.51 \\
\hline & 25.5 & 12.2 & 14.6 & 0.08 & 7.5 & 0.48 & 0.84 & 0.00 & 2.01 & 0.49 \\
\hline & 18.0 & 10.5 & 10.8 & 0.25 & 5.7 & 0.58 & 0.97 & 0.01 & 2.14 & 0.47 \\
\hline & 12.3 & 7.2 & 6.9 & 0.11 & 3.45 & 0.59 & 1.04 & 0.01 & 1.93 & 0.50 \\
\hline & 8.85 & 5.85 & 5.25 & 0.09 & 2.37 & 0.66 & 1.11 & 0.01 & 1.87 & 0.55 \\
\hline & 6.48 & 4.09 & 3.40 & 0.41 & 1.62 & 0.63 & 1.20 & 0.06 & 1.78 & 0.52 \\
\hline & 4.86 & 3.38 & 2.68 & 0.48 & 1.27 & 0.70 & 1.26 & 0.10 & 1.83 & 0.53 \\
\hline & 3.59 & 2.47 & 1.70 & 0.59 & 0.90 & 0.68 & 1.45 & 0.16 & 1.78 & 0.47 \\
\hline & 2.69 & 2.02 & 1.30 & 0.54 & 0.68 & 0.75 & 1.55 & 0.20 & 1.79 & 0.48 \\
\hline & 2.01 & 1.51 & 0.85 & 0.48 & 0.54 & 0.75 & 1.78 & 0.24 & 1.87 & 0.36 \\
\hline \multicolumn{11}{|c|}{ Gattendorfia subinvoluta (Münster, 1832) } \\
\hline \multirow[t]{2}{*}{ MB.C.9423.1 } & 54.4 & 26.5 & 23.9 & 12.2 & 14.2 & 0.49 & 1.11 & 0.22 & 1.83 & 0.41 \\
\hline & 40.2 & 20.3 & 18.2 & - & - & 0.50 & 1.12 & - & - & - \\
\hline MB.C. 9426.3 & 10.8 & 6.1 & 3.3 & 4.6 & - & 0.56 & 1.85 & 0.43 & - & - \\
\hline \multicolumn{11}{|c|}{ Globimitoceras albaillei $\mathrm{n} . \mathrm{sp}$. } \\
\hline HT UMC-IP 605 & 23.9 & 17.9 & 13.3 & 0.2 & - & 0.75 & 1.35 & 0.01 & - & - \\
\hline \multirow[t]{15}{*}{ PT UMC-IP 603} & - & 21.4 & - & 0.2 & - & - & - & - & - & - \\
\hline & - & 18.4 & - & 0.4 & - & - & - & - & - & - \\
\hline & 20.5 & 15.0 & 11.3 & 0.15 & 4.2 & 0.73 & 1.33 & 0.01 & 1.58 & 0.63 \\
\hline & 16.3 & 12.1 & 9.2 & 0.12 & 3.5 & 0.74 & 1.32 & 0.01 & 1.62 & 0.62 \\
\hline & 12.8 & 10.1 & 7.1 & 0.10 & 2.7 & 0.79 & 1.43 & 0.01 & 1.61 & 0.62 \\
\hline & 10.1 & 8.4 & 5.6 & 0.05 & 2.25 & 0.83 & 1.50 & 0.01 & 1.65 & 0.60 \\
\hline & 7.85 & 6.5 & 4.45 & 0.0 & 1.70 & 0.83 & 1.46 & 0.00 & 1.63 & 0.62 \\
\hline & 6.15 & 5.37 & 3.45 & 0.15 & 1.30 & 0.87 & 1.55 & 0.02 & 1.61 & 0.62 \\
\hline & 4.85 & 4.49 & 2.55 & 0.18 & 1.02 & 0.93 & 1.76 & 0.04 & 1.60 & 0.60 \\
\hline & 3.83 & 3.58 & 2.07 & 0.20 & 0.82 & 0.94 & 1.73 & 0.05 & 1.62 & 0.60 \\
\hline & 2.91 & 3.06 & 1.52 & 0.28 & 0.66 & 1.05 & 2.07 & 0.09 & 1.65 & 0.57 \\
\hline & 2.31 & 2.48 & 1.16 & 0.32 & 0.52 & 1.06 & 2.14 & 0.14 & 1.65 & 0.55 \\
\hline & 1.79 & 2.00 & 0.83 & 0.28 & 0.42 & 1.09 & 2.41 & 0.15 & 1.68 & 0.49 \\
\hline & 1.41 & 1.53 & 0.72 & 0.24 & 0.34 & 1.09 & 2.13 & 0.17 & 1.66 & 0.53 \\
\hline & 1.12 & 1.16 & 0.46 & 0.26 & 0.27 & 1.04 & 2.52 & 0.24 & 1.74 & 0.41 \\
\hline \multicolumn{11}{|c|}{ Gattendorfia nazairensis n. sp. } \\
\hline HT UMC-IP 591 & 48 & 39 & 24,5 & 8.5 & - & 0.81 & 1.59 & 0.18 & - & - \\
\hline \multicolumn{11}{|l|}{ Goniocyclus sp. } \\
\hline UMC-IP 634 & 25 & - & 11 & 9 & - & 0.44 & 1.22 & 0.37 & - & - \\
\hline \multicolumn{11}{|c|}{ Merocanites applanatus (Frech, 1899) } \\
\hline UMC-IP 560 & 82 & 14 & 24 & 42 & - & 0.17 & 0.58 & 0.51 & - & - \\
\hline
\end{tabular}




\begin{tabular}{|c|c|c|c|c|c|c|c|c|c|c|}
\hline & $\mathrm{dm}$ & ww & wh & uw & $\mathrm{ah}$ & $\mathrm{ww} / \mathrm{dm}$ & ww/wh & $\mathrm{uw} / \mathrm{dm}$ & WER & IZR \\
\hline \multicolumn{11}{|c|}{ Ammonellipsites kochi (Holzapfel, 1889) } \\
\hline UMC-IP 571 & 105 & - & - & 24 & - & - & - & 0.23 & - & - \\
\hline UMC-IP 572 & 41.5 & 25.2 & 18.8 & 11.5 & 10.6 & 0.61 & 1.34 & 0.28 & 1.80 & 0.44 \\
\hline \multicolumn{11}{|c|}{ Ammonellipsites hauchecornei (Holzapfel, 1889) } \\
\hline MB.C. 9434 & 56 & 27 & 26 & 14 & - & 0.48 & 1.04 & 0.25 & - & - \\
\hline UMC-IP 579 & ca. 50 & 23 & 21 & 12.5 & 12.5 & 0.46 & 1.10 & 0.25 & 1.78 & 0.40 \\
\hline UMC-IP 578 & ca. 41 & 21.5 & 18.5 & 10 & - & 0.53 & 1.16 & 0.24 & - & - \\
\hline UMC-IP 573 & ca. 38 & 19.5 & 17 & 11 & - & 0.51 & 1.15 & 0.29 & - & - \\
\hline UMC-IP 577 & ca. 26 & 15.5 & 12 & 6.5 & - & 0.60 & 1.29 & 0.25 & - & - \\
\hline \multicolumn{11}{|c|}{ Dombarites granofalcatus (Kullmann, 1961) } \\
\hline MB.C.9429.1 & 50 & 27 & 21 & 10 & - & 0.54 & 1.29 & 0.20 & - & - \\
\hline MB.C.9429.2 & 39 & 24 & 16 & 10 & - & 0.62 & 1.50 & 0.26 & - & - \\
\hline \multicolumn{11}{|c|}{ Neogoniatites canovasi n. sp. } \\
\hline HT MB.C. 9431 & 56.9 & 29.4 & 30.4 & 5.4 & 14 & 0.52 & 0.97 & 0.09 & 1.75 & 0.54 \\
\hline
\end{tabular}

